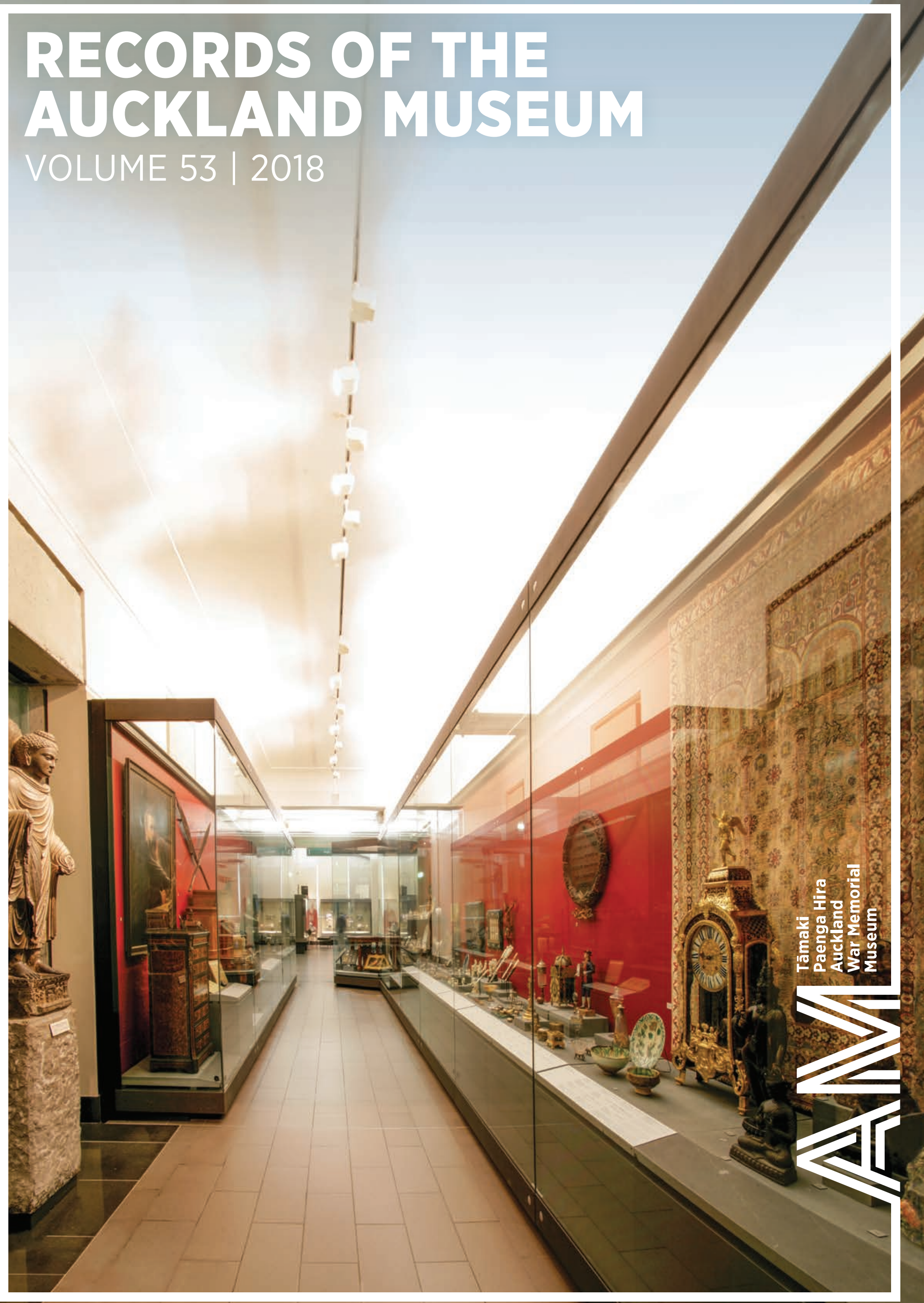




\title{
The plants of Waya Island, Fiji
}

\author{
Rhys O. Gardner Auckland War Memorial Museum
}

\begin{abstract}
An annotated species-list is given for Waya Island (Yasawa Is. Group, Fiji). It contains 38 ferns and lycophytes, 1 cycad, 55 monocotyledons, and 224 dicotyledons. Nearly all these 318 species are indigenous to Fiji or are likely to be ancient (pre-European) introductions. Except for six species, post-European introductions (weeds and cultivated species) have not been included.

Two species are endemic to Waya: Embelia deivanuae (Myrsinaceae) and Psychotria volii (Rubiaceae). Five are rare in Fiji: Guettarda wayaensis (Rubiaceae), Mollugo pentaphylla (Molluginaceae), Ormocarpum orientale (Leguminosae), Polystichum pilosum (Dryopteridaceae), and Prosaptia vomaensis (Polypodiaceae). Another two Fijian rarities, Euphorbia plumerioides (Euphorbiaceae) and Sarcolobus stenophyllus (Asclepiadaceae), were found on Waya in 1937 but have not been seen since.

Waya's taller native vegetation is situated mostly on rugged rocky topography and is dominated by members of Leguminosae (Cynometra, Kingiodendron, Maniltoa), Sapindaceae and Sapotaceae. In Fiji at large such "dry zone" cover has been greatly reduced by continual fires, so Waya's remnants, though small and discontinous, have substantial biodiversity value.
\end{abstract}

\section{Keywords}

Waya Island; Yasawa Islands; Fiji archipelago; higher-plant species; dry-zone forest.

\section{INTRODUCTION}

This account of the higher-plants found on the small Fijian island of Waya mainly concerns species native to Fiji, but a number of post-European introductions have been included too - in total 318 species are treated. It is largely based on specimens collected by Harold St John in 1937 and cited in A. C. Smith's Flora Vitiensis Nova, and on collections made by the author in 1991, 1992 and 2017. St John seems to have been the first botanist to visit Waya - although both the U.S. Exploring Expedition in 1840 , and Berthold Seemann in 1860, made collections from a range of Fiji's islands they did not make landfall in the Yasawas. Since St John's time, this group of islands has been collected from only infrequently (Smith 1979: 76). I hope to show that this neglect is undeserved.

I have written twice already on Wayan botany: on my most noteworthy finds (Gardner 1997), and on plantnames in the Wayan ("West Fijian") language (Gardner $\&$ Pawley 2006). The latter article makes no mention of those indigenous species - mainly the less common ones and those of no use to humans - that lack a Wayan name.

\section{THE SETTING}

Waya is located at the southern end of the Yasawa Islands chain, $50 \mathrm{~km}$ off the northwestern coast of Fiji's largest island, Viti Levu (Fig. 1). It is a "high" (volcanic) island, irregularly circular in outline, c. $7 \mathrm{~km}$ in diameter and 2100 ha. in extent. Its rugged topography, deriving from andesitic flows, agglomerates and tuff, reaches 510 $\mathrm{m}$ (1673 feet) at the peak of Vatunareba in the southeast, overlooking the bay of Yalobi. The highest point, of 561 $\mathrm{m}$ (1841 feet), is reached in the northeast by the less dramatic peak of Uluiwaya.

Yalobi (to early Europeans, Alacrity Bay) on the southern coast is the largest of the island's several, reef-fringed bays. In Yalobi village, and in the island's three other coastal villages, Nalauwaki, Waya Levu, Natawa, there live c. 1200 people, their lifestyle based on fishing and gardening (cassava, bananas, yams), together with income from cruise-ship visits, backpacker tourism, and off-island work, e.g., in Fiji's tourist resorts (Waya has just one of these).

Human occupation of Waya goes back 2,500 years or more (Hunt et al. 1999), so it is unlikely that any of the existing taller vegetation can be thought of as "original". The slopes above the gardened valleys are mainly of induced grassland or scrub, with forest only in those areas too steep or too rocky to cultivate and where fire cannot get to. There are considerable areas of bare or scrubby rocky ground on Vatunareba.

The central part of the island consists of broken topography between the island's two high- points. Relatively well-forested, it is the watershed for a number of small streams, but in its more fertile places trees are continually being felled, often for the cultivation of agona (the kava plant, Piper methystichum). 


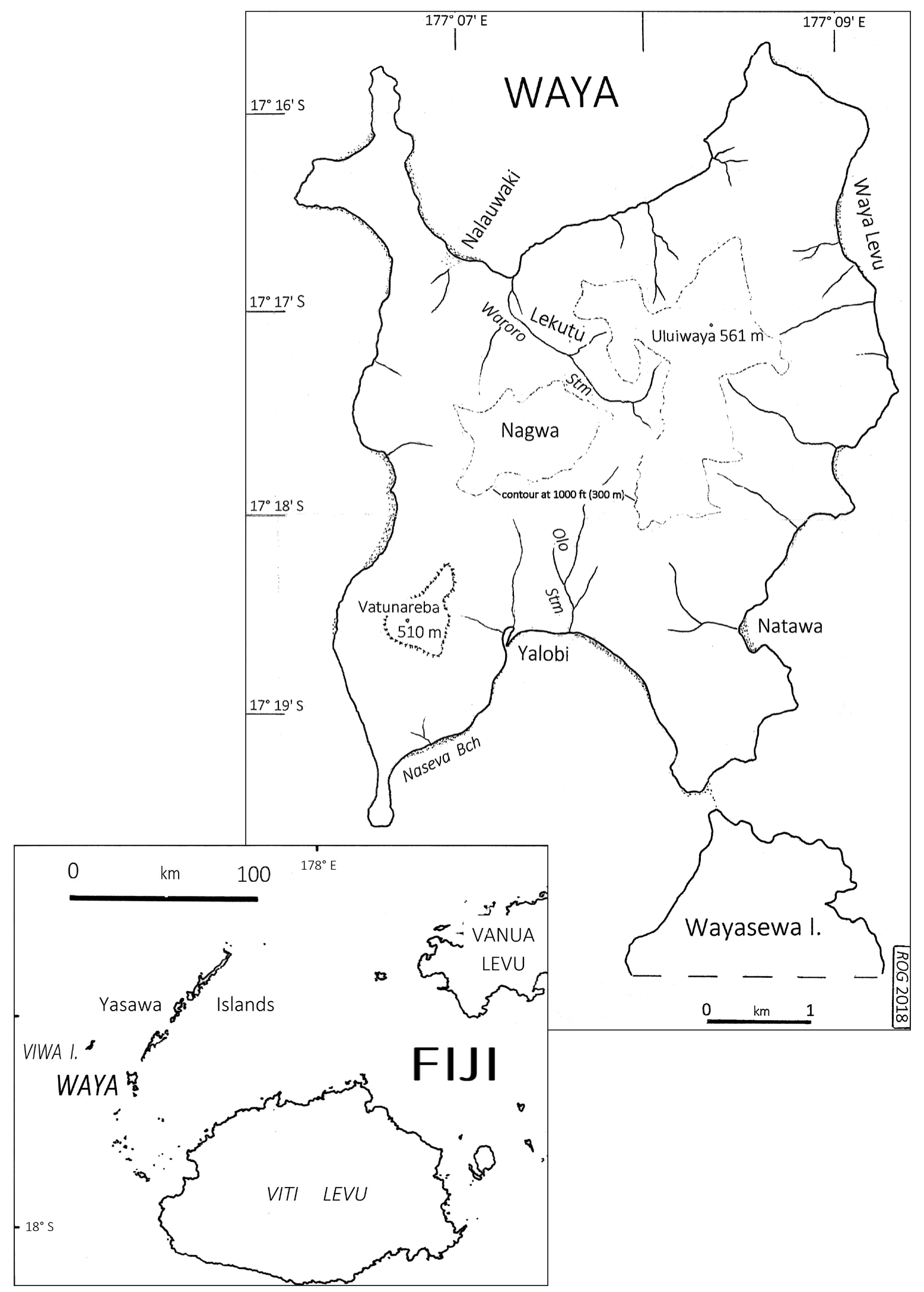

Figure 1. Waya Island. Based on the chart "Yasawa Islands, Fiji. Sheet 1: Waya Group", surveyed by A. H. Pickmere. Alexander Turnbull Library, Wellington. [Privately published 1973; reproduced here with the permission of the copyright holder Janet M. Watkins, Auckland]. Note: the location of "Lekutu" is approximate only. 
Waya has a climate similar to that of the eastern (leeward) coast of Viti Levu, with a distinctly dry, cool season during the middle part of the year (Derrick (1957: 108; Twyford \& Wright 1965: 76). This dryness is intensified by the often very shallow character of its predominantly steepland soils (Twyford \& Wright 1965: 491). The island then has special ecological and conservation interest, with "dry zone forest" now greatly depleted not just on the larger Fijian islands but in the New Caledonia-Fiji-Tonga region at large (MuellerDombois \& Fosberg 1997; Gillespie \& Jaffré 2003; Keppel \& Tuiwawa 2007).

Most of Waya's coastal and low- to mid-altitude forest has gone, but the woody plants that remain can be taken to indicate what "dry zone forest" here was like:

a) a low presence of "moist rainforest" taxa, e.g., absence of Arecaceae, Elaeocarpaceae and Podocarpaceae, only one member of Hymenophyllaceae (Trichomanes atrovirens), only one member of Lauraceae (Litsea vitiana), absence of Elatostema (and the wide-ranging Procris pedunculata is present but rare), and just one species each of Cyrtandra and Medinilla (both rare on Waya);

b) an abundance of species belonging to Anacardiaceae, Ebenaceae, Sapindaceae and Sapotaceae; abundance of Geissois ternata (Cunoniaceae); local dominance of legume trees, that is, species of Cynometra, Kingiodendron, Maniltoa and Serianthes - cf. the dry Maniltoa-Pleiogynium forest of the Tonga island of Eua (Mueller-Dombois \& Fosberg 1997: 353);

c) a predominance of drought-resistant species in the regrowth communities: Dodonaea viscosa, Ficus barclayana, Mallotus tiliifolius, Melochia degeneriana and Parasponia andersonii, these small trees together with semi-scandent "cast-iron" shrubs such as Rhamnella vitiensis, Smythea lanceata and Ventilago vitiensis (all Rhamnaceae), and Celastrus richii (Celastraceae).

Although Waya's forest and scrub is now very discontinuous it is still "natural" in that the most aggressively weedy trees of other dry parts of Fiji notably the legumes Adenanthera pavonina, Albizia saman, and Leucaena leucocephala, are relatively restricted in extent.

Waya's ecological values are also greatly enhanced by the absence of that Fijian pest the small Asian mongoose, Herpestes javanicus. Consequently, smaller lizards are abundant, and also, Fiji's largest and most endangered lizard, the Fijian crested iguana (Brachylophus vitiensis), is still regularly sighted. Unfortunately for its indigenous plants though the island is home to a fair number of goats, their introduction dating back to the late 1940 s or early '50s (A. Pawley pers. comm.).

\section{SCOPE AND STYLE}

No keys or descriptions of the families and genera represented in Waya's flora are given here. However, scans of herbarium specimens of some of the more notable species (mostly those endemic to Fiji, or species indigenous to Fiji but uncommon there) can be found on the web-site of the Auckland War Memorial Museum (http://www.aucklandmuseum.com/collections-research/ collections/search). All are my own Wayan collections, housed in the herbarium of this museum.

In the main text below the species are arranged alphabetically by family, within the following sequence: 38 ferns and lycophytes (Lycopodiella, Psilotum and Selaginella); 1 gymnosperm (a species of Cycas); 55 monocotyledons; 224 dicotyledons. A concise listing is given in Appendix 1.

A number of the species treated are probably not indigenous to Fiji. Most of these are likely to have been introduced in pre-European times, being food-plants or weeds associated with the peopling of the Pacific Ocean region. Six species likely to be modern introductions have been included, either because they are so conspicuous in the Wayan landscape, e.g., the grassland-dominant Cenchrus polystachios, or because they represent a new distribution record, e.g., Adiantum trapeziforme. Also, coastal species not so far known from Waya but occurring (or likely to occur) $27 \mathrm{~km}$ westwards on the atoll of Viwa I. have been included.

Two species appear to be endemic to Waya: Embelia deivanuae (Myrsinaceae) and Psychotria volii (Rubiaceae). Two species of wide distribution westwards of Fiji, Carex brunnea and Rinorea benghalensis, are currently known in the Fiji archipelago only from Waya. Two or possibly three Wayan species appear to be rare Fijian endemics: Guettarda wayaensis, Polystichum pilosum and possibly Prosaptia vomaensis. The legume tree Serianthes vitiensis, rare on Waya, is known otherwise by only two or three old collections from Vanua Levu. St John collected two rare Fijian plants I was unable to find: the widespread Euphorbia plumerioides, and the Fijian endemic Sarcolobus stenophyllus (Asclepiadaceae).

\section{SCIENTIFIC NAMES}

Names for the ferns and lycophytes, including family ones, have been updated from those of Brownlie (1977), using mainly the checklist of Brownsey \& Perrie (2011). For the flowering-plant genera and families Flora Vitiensis Nova (hereafter, FVN) has largely been adhered to, in order to assist reference to that comprehensive work's keys etc. However, three updated placings have been made: Cordyline is transferred into Asparagaceae, Dianella into Xanthorrhoeaceae, and all legumes into Leguminosae. Also, because FVN's family-level classification is now seriously out of date, reference is sometimes made to the latest scheme ("APG IV") of the Angiosperm Phylogeny Group (2016), e.g., "Casearia FLACOURTIACEAE (APG IV Salicaceae)". Where names at specific or generic level have been updated, the ones used by Brownlie (1977) or FVN are given using the phrase "Formerly known as X". 


\section{WAYAN PLANT NAMES}

The language of Waya belongs to the Western Fijian Language grouping (Geraghty 1983: 268). The Wayan plant-names offered in the present work do not include the obsolete ones (cited as such by Gardner \& Pawley 2006). These names, recorded by St John but not confirmed by me in 1991/2, have been included here in the citation of St John's specimens, with modern spelling added if necessary.

\section{THE SPECIMENS}

Except for a relatively small number of entries (mainly sight-records of the writer) this work is specimen-based. Almost all the specimens were collected by St John or me, but a few others have been added from the citations of FVN. For the identification of St John's specimens reliance has been placed on Brownlie (1977), FVN, and modern revisions. Some of St John's Wayan collections at US can be viewed at that institution's online database.

Collection details for St John and me are as follows (modern spellings in brackets):

\section{St John}

Collection numbers 18005-18173, made 15-22 July 1937; specimens at BISH in the first instance, with some duplicates at US and (at least of some ferns) at SUVA. The numbers (which include several bryophytes) and their localities are:

18005-18012, 18030, 18059-18060, 18089-18097, 18171-18173 Yalobi

18013-18029 Olo Creek, N of Yalobi

18031-18058 Naruarua Gulch, W side of Batinareba [Vatunareba]

18061-18067 woods along Waroro Creek

18068-18088 woods along Wailevu Creek 18098-18120, 18153-18170 Nagua [Nagwa]

18121-18130 woods along Olo Creek, N of Yalobi

18131-18152 Nakawa Gulch, W side of Batinareba

[Vatunareba]

St John's obsolete plant-names are cited as written in his notebook (BISH), as are the names of his localities (which are cited only where I did not rediscover the species). The exact location of St John's two gullies ("gulches"), on the west side of Vatunareba, and his "Wailevu Creek", seem to be unknown to the Wayan people of today.

\section{R.O. Gardner}

My specimens, which were obtained from numerous localities on Waya, are numbered 6249-6541 (27 Oct to 15 Nov 1991), 6654-6890 (12 July to 16 August 1992), and 11291-11344 (2-11 June 2017). Their label-notes on habitat etc., have sometimes been rewritten in the present work, in the interest of brevity and clarity. A first set of these collections is at AK; others are at BISH, CHR, SUVA and US.

\section{THE ENTRIES}

If a species is endemic to Fiji this is stated. For distribution within the Fijian archipelago the data offered here is just a summary of that in Brownlie (1977) and FVN. These works were based on a thorough knowledge of the Fijian collections gathered up to that time, so they should still be adequate, at least for comparative and conservation purposes. For abundance on Waya itself some indication is often given in the specimen-notes.

All St John specimens cited in FVN, but only the most informative of the my own have been included in the species-entries.

In the entries the citing of synonyms and references has been kept to a minimum. To find more about a particular Wayan fern or lycophyte's taxonomic history, and relevant keys and descriptions, see Brownlie (1977), Orchard \& McCarthy (1998), Nakamura \& Matsumoto (2008), and Chen et al. (2017). For flowering plants the best source of such data is FVN, but it is not yet available as an e-book. However, the two classic accounts of Fiji's flowering plants, Asa Gray's (1854) U.S. Exploring Expedition volume (only partly about Fiji) and Berthold Seemann's Flora Vitiensis (186573), are available at free-access Web sites like Botanicus and Biodiversity Heritage Library. When referring to Gray and Seemann I have noted page numbers, which will make it unnecessary to first consult FVN or other secondary sources.

Gray is still worth reading, for his expressive descriptions. Seemann's descriptions are in Latin but his long asides on Fijian ethnobotany and history, e.g., on Cocos, Excoecaria, Ficus obliqua, Piper methysticum, Santalum and Tacca, are in English. Both works, and also the U.S. Exploring Expedition volume on ferns (Brackenridge 1855) contain superb illustrations of Fijian plants, and these have been noted in the species-entries.

\section{SIGNS AND ABBREVIATIONS}

* Superscript before species' name indicates a likely introduction in post-European times.

$\varnothing \quad$ diameter

dbh diameter breast height (of a tree trunk)

E east(ern)

flr(s) flower(s)

Illn illustration

infl., infls. inflorescence(s)

1.s. longitudinal section

occ. occasionally

NW north-west(ern), SE south-east(ern), etc.

t.s. transverse [cross-]section

us. usually

FV Flora Vitiensis [B. Seemann 1865-73]

FVN Flora Vitiensis Nova [A.C. Smith, 1979-91]

USEE 15, Atlas U.S. Exploring Expedition Vol. 15, Atlas [A. Gray, 1856]

USEE 16, Atlas U.S. Exploring Expedition Vol. 16, Atlas [W. Brackenridge, 1855] 
AK Botany Department, Auckland War Memorial Museum, Auckland, New Zealand

BISH Herbarium Pacificum, Bishop Museum, Honolulu, Hawaii

CHR Allan Herbarium, Landcare Research, Lincoln, New Zealand.

DA Department of Agriculture, Fiji (herbarium collection series; first set at SUVA).

SUVA South Pacific Regional Herbarium, University of the South Pacific, Suva, Fiji

TNS National Museum of Nature and Science, Tsukuba, Japan

US United States National Herbarium (Smithsonian Institution), Washington D.C., U.S.A.

\section{FLORA, PART 1: FERNS, LYCOPHYTES, CYCAD}

\subsection{ASPLENIACEAE}

Asplenium amboinense Willd.

Abundant in Fiji's forests. ROG 6796, E side of peaks above Waya Levu, occ. in mesic places in forest. Illn: USEE 16, Atlas pl. 19 fig. 2.

Asplenium polyodon G. Forst.

In Fiji most abundant in higher-altitude forests of the larger islands. St John 18033, "tokalo". Illn: USEE 16, Atlas pl. 22 fig. 1, as A. falcatum var. attenuatum.

\subsection{BLECHNACEAE}

Blechnum orientale $\mathrm{L}$.

Widespread in Fiji's forests. St John 18061, "ndondobalawa".

\subsection{CYATHEACEAE}

Cyathea lunulata (G. Forst.) Copel. balabala Widespread in Fiji, often abundant. St John 18098, “mbalambala". ROG 6336, -7, near Nagwa, to $7 \mathrm{~m}$ tall $15 \mathrm{~cm} \mathrm{dbh}$, in damp gullies in secondary forest. Illn: USEE 16, Atlas pl. 39, as "Alsophila lunulata R.Br. ?". Holttum (1964:267) considered that this plate represents the Fijian plant, i.e., the endemic subspecies C. lunulata subspecies vitiensis (Carr.) Holttum.

\subsection{DAVALLIACEAE}

\section{Davallia heterophylla Sm.}

Widespread in Fiji's lowland forests. St John 18157, "kara". Formerly known as Humata heterophylla.

Davallia solida (G. Forst.) Sw.

Widespread on Fiji's dry-zone coasts, including those of the smaller islands. ROG 6438, towards the peaks $\mathrm{N}$ of Yalobi, on shady rock cliffs away from goats.

\subsection{DENNSTAEDTIACEAE}

\section{Microlepia speluncae (L.) T. Moore}

Rather local in Fiji (Waya, the three largest islands, and Ovalau). ROG 6514, slope NW of Vatunareba, common in open bouldery forest.

Pteridium esculentum (G. Forst.) Cockayne mata Abundant locally in the drier parts of Fiji's two largest islands. No specimen known from Waya, but species presence recorded on label of ROG 6536 (Pteris vittata).

\subsection{DICKSONIACEAE}

\section{Calochlaena straminea (Labill.)}

M.D. Turner \& R.A. White balabala leke Widespread in Fiji, in open mesic forest sites. St John 18064. ROG 6341, Nagwa, uncommon in shady secondary forest. Formerly known as Culcita straminea. Illn: USEE 16, Atlas pl. 38 fig. 2, as Dicksonia torreyana.

\subsection{DRYOPTERIDACEAE}

Polystichum pilosum Copel.

Endemic to Fiji, rare; in open forest or scrub, known just from Waya and two dry montane localities (Ba, Viti Levu; Macuata, Vanua Levu). ROG 6785, towards Vatunareba summit, occ. in uppermost gully forest.

\subsection{GLEICHENIACEAE}

Dicranopteris linearis (Burm.f.) Underw. mata Common in Fiji's dry regions, often with Pteridium esculentum. St John 18071, "kavindi".

\subsection{HYMENOPHYLLACEAE}

Trichomanes atrovirens (C. Presl) Kunze Widespread and abundant in Fiji's forests, St John 18122, "rhausongiri". ROG 6863, E of Koroimatalevu peak (high point S of Lekutu), local on clay banks of stream in shady forest. Formerly known as Trichomanes boryanum.

\subsection{LOMARIOPSIDACEAE}

Nephrolepis hirsutula (G. Forst.) C. Presl digi Abundant in Fiji. ROG 6377, Yalobi to Nalauwaki track, occ. at forest edges and straggling among Miscanthus. In Gardner \& Pawley (2006) this collection was identified as $N$. biserrata (Sw.) Schott. I now think it agrees better with $N$. hirsutula, having dark-centred appressed scales on the base of the stipe, and rachisscales that are red-brown, acuminate and strongly dentate distally (Hovenkamp \& Miyamoto 2005). 


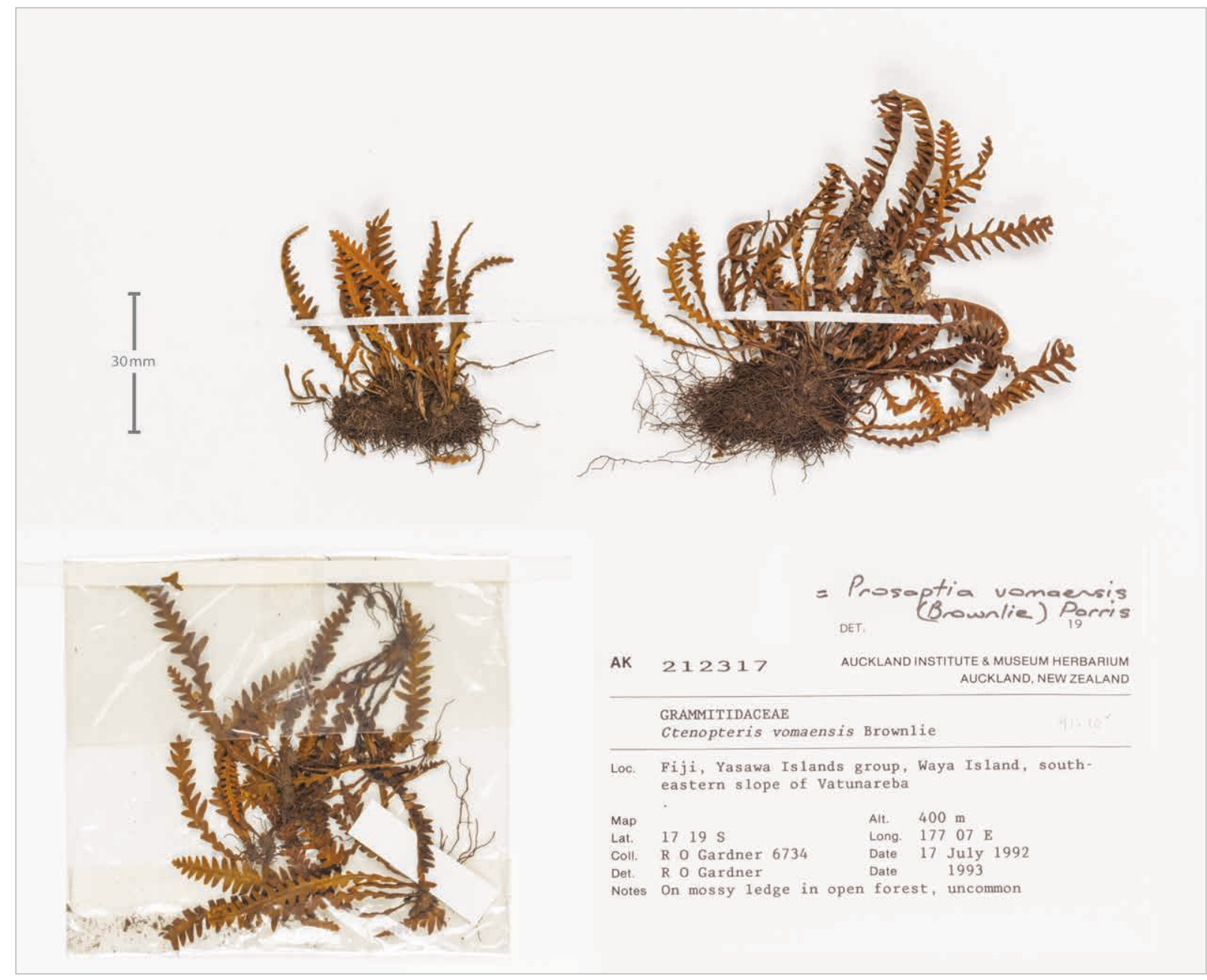

Figure 2. Prosaptia vomaensis, AK212317. (c) Auckland Museum CC BY.

\subsection{LYCOPODIACEAE}

\section{Lycopodiella cernua (L.) Pic.Serm.}

Abundant in Fiji. St John 18068, "o ranaranga". Formerly known as Lycopodium cernuum.

\subsection{LYGODIACEAE}

\section{Lygodium reticulatum Schkuhr}

vere lumuka

In Fiji widespread on forest margins and in secondary forest. ROG 6251, Yalobi, common in dryish scrub. Wrongly cited as L. articulatum by Gardner \& Pawley (2006: 107).

\subsection{MARATTIACEAE}

Angiopteris evecta (G. Forst.) Hoffm.

bāwale

Widespread and abundant in Fiji's wetter forests. St John 18114. ROG 6489, peaks W above Nagwa, in dense forest away from goats, uncommon.

\subsection{POLYPODIACEAE}

Drynaria rigidula (Sw.) Bedd.

sova ni gwata

Widespread in Fiji, especially in open forest. St John 18046, "temba". ROG 6456, slope W of Yalobi, perching on older trees.

\section{Microsorum grossum (Langsd. \& Fisch.)}

S.B. Andrews

vativati

Widespread in Fiji's dry open forests. ROG 6320, gardens in valley NW of Yalobi, edge of relic forest among boulders. Formerly known as Phymatosorus grossus.

\section{Prosaptia vomaensis (Brownlie) Parris}

Perhaps endemic to Fiji, in rocky forest (Waya, Viti Levu) at mid-altitude. ROG 6734, SE slopes of Vatunareba, on mossy ledge in open forest, uncommon. Formerly known as Ctenopteris vomaensis. Recorded from Vanuatu (Nakamura \& Matsumoto 2008: 249) but a voucher cannot be located (A. Ebihara of TNS, pers. comm. March 2015). Fig. 2. 
Pyrrosia lanceolata (L.) Farw.

tuāida

Widespread in drier forests of Fiji. St John 18141, "komokomo". ROG 6688, SE slopes of Vatunareba, uncommon epiphyte in gully forest. Formerly known as Pyrrosia adnascens.

\subsection{PSILOTACEAE}

Psilotum nudum (L.) P. Beauv. velau kai Widespread in Fiji. ROG 6665, above Olo stream, a few plants on ledge of shaded rock face, seemingly uncommon on the island.

\subsection{PTERIDACEAE}

Acrostichum aureum L.

būrete

Widespread in Fiji at the rear of mangrove and in other estuarine situations. No specimen known from Waya, but sighted in the mangrove at Yalobi (obs. ROG 1990s).

\section{Adiantum hispidulum Sw.}

Widespread in Fiji, in open dry places. St John 18081, "tokalo".

\section{* Adiantum trapeziforme L.}

Native to tropical America; naturalized in Fij on Waya, and in southern Viti Levu (Brownsey \& Perrie 2011: 526). $R O G$ 6864, stream $\mathrm{E}$ of Koroimatalevu peak (high point $\mathrm{S}$ of Lekutu), local in open hillside regrowth.

Antrophyum plantagineum (Cav.) Kaulf. Widespread in Fiji's wetter forests. St John 18048.

\section{Cheilanthes nudiuscula (R.Br.) T. Moore}

Local in Fiji (Waya and the three largest islands), in dry open rocky places. St John 18148. ROG 6453, slope W of Yalobi, occ. on rocky ledges. Formerly known as $C$. hirsuta.

\section{Doryopteris concolor (Langsd. \& Fisch.) Kuhn}

Widespread in Fiji in dry open rocky places, sometimes on limestone. St John 18083, "turalo". ROG 6454, 11311 , slope W of Yalobi, occ. on rocky ledges.

\section{Haplopteris elongata (Sw.) E.H. Crane}

Widespread in Fiji's wetter forests. St John 18049, "o ni koro". Formerly known as Vittaria elongata.

\section{Pteris tripartita Sw.}

Widespread in Fiji. ROG 6515, slope NW of Vatunareba peak, local in open forest of bouldery slope on good soil, "[a kind of] balabala".

\section{* Pteris vittata $\mathrm{L}$.}

Probably not native to Fiji (rare here, known only from Waya and Viti Levu). ROG 6536, high point on E side of Olo stream, local on burnt knoll, on shallow soil; Dicranopteris and Pteridium also seen only here.

\section{Taenitis pinnata (J. Sm.) Holttum}

Rather local in Fiji, in mesic and somewhat shaded forest sites. St John 18063, "totondro lo". ROG 6755, peaks E above Yalobi gardens, local in shady dry forest.

\subsection{SCHIZAEACEAE}

Schizaea dichotoma (L.) Sm.

Widespread in Fiji, in all vegetation types, from Pteridium fernland to dense forest. St John 18020, "seisei”.

\subsection{SELAGINELLACEAE}

\section{Selaginella firmula A. Braun ex Kuhn}

Endemic to Fiji, widespread in forest, often abundant. St John 18022. ROG 6866, stream E of Koroimatalevu (high point S of Lekutu), on stiff clay at edge of stream terrace in shady forest.

\section{Selaginella laxa Spring}

Widespread in Fiji in damp to mesic open forests. No specimen known from Waya, but seen by $R O G$ in 2017 , on Vatunareba (soil overhangs at upper edge of shady ravines), and along the higher part of Olo stream, in scrubby cover close to the water.

\section{Selaginella victoriae T. Moore}

Endemic to Fiji, in mesic to rather dry forests, widespread. St John 18021, "mbambaranga”. ROG 6340 , Nagwa, locally common in older forest.

\subsection{TECTARIACEAE}

Tectaria latifolia (G. Forst.) Copel.

Widespread and often abundant in Fiji's drier forests. St John 18014, "gutivi". ROG 6303, Olo stream, abundant among rocks in relic streamside forest.

\subsection{THELYPTERIDACEAE}

Macrothelypteris torresiana (Gaudich.) Ching Local in Fiji, mainly on the two largest islands, in dry open sites. ROG 6418, slope above Naseva Beach, among boulders in open forest.

Sphaerostephanos invisus (G. Forst.) Holttum digi Common in Fiji, in open ground. ROG 6314, E of Olo stream, occ. in rocky tall forest on slope.

\subsection{CYCADACEAE}

Cycas celebica Miq. niuniu Common in drier regions of Fiji. St John 18045, "wiro". $R O G$ 6419, slope above Naseva Beach, abundant in burnt scrub and grassland, only the youngest leaves nibbled by goats. Sometimes known as Cycas rumphii f. seemannii (de Laubenfels \& Adema 1998: 371). St John's name was misspelt "wairo" by Gardner \& Pawley (2006: 108). 


\section{FLORA, PART 2: MONOCOTYLEDONS}

\subsection{ARACEAE}

\section{Alocasia macrorrhizos (L.) G. Don}

via sam

Anciently cultivated in Fiji, often persisting or naturalizing at least by vegetative means. $R O G$ 6356, gardens in valley NW of Yalobi, scattered in the lower, damper places, ripe fruit. $R O G$ 6513, slope NW of Vatunareba, common in open forest on bouldery slope, in good soil.

\section{Amorphophallus paeoniifolius}

(Dennst.) Nicolson

abia $s \bar{a}$

Widespread in Fiji (anciently introduced ?) mainly in disturbed coastal forest. ROG 6517, slope NW of Vatunareba, occ. in open forest on good soil of bouldery slope.

Cyrtosperma merkusii (Hassk.) Schott via kau Anciently cutivated in Fiji, often naturalized in wet places. $R O G$ 6333, gardens in valley NW of Yalobi, cultivated. Formerly known in the central and eastern Pacific as C. chamissonis.

Epipremnum pinnatum (L.) Engl. alu Common in Fiji's forests. St John 18056. ROG 6309, Olo stream, climbing over rocks and trees in shady streamside forest.

\subsection{ARECACEAE}

Cocos nucifera $\mathrm{L}$. niu

Ubiquitous in Fiji. No specimen known from Waya. Sighted by ROG (1990s, 2017) at Yalobi, etc., cultivated, and sporadic in coastal forest.

Pritchardia pacifica Seem. \& H. Wendl. māsei Widely cultivated in Fiji since pre-European times. No specimen is known from Waya, but the plant was sighted by $R O G$ at Yalobi in 2017, where a tree c. 5 $\mathrm{m}$ tall stands at the site of the former bure of the Tui Waya. There are no wildings on the scrubby slopes around, perhaps because the seeds are avidly eaten by rats (D. Watling, pers. comm. 2014). Illn: FV t. 79.

\subsection{ASPARAGACEAE}

Cordyline fruticosa (L.) A. Chev. $\bar{a} k o t o$, qolo Widespread in Fiji, in cultivation and as a forest understorey plant. St John 18075. ROG 6319, gardens in valley NW of Yalobi, occ. in relic forest. Illn: FV t. 94, as Dracaena sepiaria.

\subsection{CYMODOCEACEAE}

\section{Halodule pinifolia (Miki) den Hartog}

lēcau

Widespread and often abundant on Fiji's coast. ROG 6449 , between Yalobi and Naseva Beach, local on shallow sandy reef-flat. $R O G$ 6831, Yalobi, a few patches on sand on coral platform a short way below high-water mark, with Halophila minor.
Syringodium isoetifolium (Aschers.) Dandy lēcau Quite frequent on Fiji's muddy reef-flats. ROG 6829, beach at Yalobi, abundant in the drift.

\subsection{CYPERACEAE}

\section{Carex brunnea Thunb.}

In Fiji known just from the highest part of Waya (Gardner 1997: 491). ROG 6508, 6672, SE Vatunareba, locally common in open forest above c. $300 \mathrm{~m}$, amongst Scleria lithosperma.

\section{Carex dietrichiae Boeck.}

In Fiji's forests, perhaps widespread. ROG 6849, E side of peaks above Waya Levu, in ridge thicket. Listed as a dry-zone Fijian forest species by Keppel \& Tuiwawa (2007: 561). Fig. 4

\section{Cyperus javanicus Houtt.}

Common in Fiji, usually near beaches and creek mouths. ROG 6396, Waya Levu, on gravel berm at beach rear. Sometimes known as Mariscus javanicus.

Fimbristylis cymosa $\mathrm{R}$. Br.

Uncommon in Fiji (Viti Levu and Viwa I.), on rocks at the coast. No specimen known from Waya, but sighted on Viwa I. in July 1992; see label of ROG 6771, Sesuvium portulacastrum.

\section{Fimbristylis dichotoma (Burm. f.) Kern}

Abundant in Fiji, usually weedy in open ground. $R O G$ 6302 , near sandy mouth of Olo stream.

\section{Fimbristylis ovata (Burm. f.) Kern}

Widespread in Fiji in dry open ground. St John 18129, "dodobawale". ROG 6803, above Yalobi school, common among grasses on dry hillside.

\section{Gahnia aspera (R. Br.) Spreng.}

In Fiji's dry forests, infrequent. ROG 6460, slope $\mathrm{W}$ of Yalobi, rare in forest of dry gully, ripe fruit. Listed as a dry-zone forest species by Keppel \& Tuiwawa (2007: 561).

\section{Rhynchospora corymbosa (L.) Britton}

Abundant in Fiji, in swamps, along streams, and as a weed. St John 18080, "o nice". ROG 6802, Yalobi, in wet ground below school water-tanks, not seen elsewhere.

\section{Scleria lithosperma (L.) Sw.}

Widespread and abundant in Fiji. St John 18015, "weisa". ROG 6254, Yalobi, $30 \mathrm{~cm}$ high tussocks, common in dryish scrub, ripe fruit.

Scleria polycarpa Boeck. benici

Abundant in Fiji's drier forests. St John 18016, "nitiniti". ROG 6253, Yalobi, to c. $1.5 \mathrm{~m}$ tall, in dryish open scrub and on grassy hillsides; ripe fruit. 


\subsection{DIOSCOREACEAE}

Dioscorea bulbifera L.

qwā karai

Widespread in Fiji in dry open places. ROG 6342, near Nagwa, abundant in overgrown garden. ROG 6437, valley NW of Yalobi, regrowing abundantly on recently burnt slopes.

Dioscorea pentaphylla $\mathrm{L}$. kwaileni

Widespread in Fiji in dry open places. ROG 6468, Lekutu, in aqona garden, perhaps kept on from the wild.

\subsection{HEMEROCALLIDACEAE (APG IV: Asphodelaceae)}

Geitonoplesium cymosum (R. Br.)

A. Cunn. ex Hook.

wā bitubitu

Local in Fiji's forests (mainly Viti Levu). ROG 6806, peaks $\mathrm{E}$ above gardens in valley NW of Yalobi, climbing at scrub margin on dry ridge, uncommon here, not seen elsewhere on island.

\subsection{HYDROCHARITACEAE}

Halophila minor (Zoll.) den Hartog Abundant on Fiji's shores. ROG 6813, Yalobi, a few patches on sand at $\mathrm{W}$ end of beach.

\subsection{ORCHIDACEAE}

\section{Calanthe triplicata (Willemet) Ames}

Common in Fiji's forests. ROG 6486. peaks W above old Nagwa village site, on ground in dense forest, away from goats.

Dendrobium tokai Reichenb. f. ex Seem.

Widespread epiphyte in Fiji's forests. St John 18051, "viavia ni delana". ROG 6696. SE slopes of Vatunareba, in dry forest, rare here.

\section{Eulophia pulchra (Thouars) Lindl.}

Scattered in Fiji's lower-altitude forests (Waya and five other islands). St John 18024, Olo Creek, N of Yalobi, "parapara".

\section{Liparis condylobulbon Rchb. $\mathrm{f}$.}

Widespread and oftenabundant in Fiji's drier forests. $R O G$ 6812, peaks $\mathrm{E}$ above gardens in valley $\mathrm{NW}$ of Yalobi, low on tree trunk in open Geissois forest.

\section{Oberonia equitans (G. Forst.) Mutel}

Widespread in Fiji's drier forests (most common on Viti Levu). ROG 6847, E side of peaks above Waya Levu, epiphytic in open ridge-crest thicket, at one place only.

Pseuderia smithiana C. Schweinf.

Endemic to Fiji, rather local (Waya, Viti Levu, Vanua Levu, Kandavu). St John 18158, close to rocky summit, climbing over trees, "theme".
Spathoglottis pacifica Rchb. f.

Widespread and abundant in Fiji's grassland and dry open scrub. St John 18069, "varavara". ROG 6823, SE side of ridge above Yalobi-Waya Levu track, in light Arytera-Guioa dry forest.

Taeniophyllum fasciola (G. Forst.) Seem.

Widespread in Fiji, in forest and often on cultivated trees too. No specimen known from Waya; seen by $R O G$ in 2017 in forest on SE slope of Vatunareba.

\subsection{PANDANACEAE}

Freycinetia urvilleana Hombron \& Jacq. $\quad w \bar{a} m \bar{e}$ Widespread in the forests of Fiji (known from six high islands, including Waya). ROG 6715, high point NE of Olo stream, common low climber in forest around summit. The Fijian plants are sometimes segregated as the endemic F. milnei Seem.

Pandanus tectorius Sol. ex Parkinson vadra Common in coastal parts of Fiji. St John 18132, "vandu [va $d u$ ]", 18138, "vandra". ROG 6481, slope W of Yalobi, $3 \mathrm{~m}$ tall in forest of rocky gully, ripe fruit. The Wayan plants have been segregated as $P$. yasawaensis. This is said to have notably small (4 cm long) phalanges, and to grow only on Waya and in the vicinity of Sigatoka on Viti Levu (FVN 1: 489). It seems likely it is just a small-leaved inland ecotype of $P$. tectorius.

\subsection{POACEAE}

* Cenchrus polystachios (L.) Morrone manivusi Introduced to Fiji, now abundant in the dry grasslands of the two largest islands, and on Waya. ROG 6300, Yalobi, dominating dry grassy slope. Formerly known as Pennisetum polystachyon.

\section{Centotheca lappacea (L.) Desv.}

Widespread in Fiji's forests. No specimen known from Waya; presumed present but rare.

\section{Chrysopogon aciculatus (Retz.) Trin.}

Widespread in Fiji, often near the coast. No specimen known from Waya; seen by $R O G$ in 2017 on dry grassy slopes above Yalobi.

Coix lacryma-jobi L. sìlā

Widespread in Fiji, weedy in damp open sites. $R O G$ 6369 , near Nagwa, local at stream edge.

\section{* Cymbopogon coloratus}

(Hook. f.) Stapf $\bar{o}$ cagicagi

An introduction, now found locally in Fiji (Waya, Viti Levu) in dry open places. ROG 6738, SE slopes of Vatunareba, open lava slope, one tussock on soil patch. Brought to Fiji from India in the early 1900s in error for the true lemon-grass C. citratus (FVN 1: 380); wrongly noted as indigenous to Fiji by Gardner \& Pawley (2006: 103). 
Cymbopogon refractus $\mathrm{R}$. $\mathrm{Br}$.

$\bar{o}$ cagicagi

Widespread in Fiji on dry open hillsides. St John 18102. Gardner \& Pawley (2006: 103) may have been wrong in saying that this grass is not indigenous to Fiji.

\section{Cyrtococcum oxyphyllum (Hochst. ex Steudel) Stapf}

Widespread in Fiji, in light dry forest and as a weed. St John 18127, "o salasala". ROG 6313, east of Olo stream, common grass of shady tall relic forest in dryish gullies.

\section{Digitaria setigera Roth ex Roem. \& Schultes}

Widespread but uncommon in Fiji. No specimen known from Waya; presumed present.

\section{Heteropogon contortus (L.) P. Beauv.} ex Roem. \& Schultes

Local in drier regions of Fiji (the two largest islands, and Waya). in grassland . ROG 6804, Yalobi, above the school, local on dry grassy ridge, $40 \mathrm{~cm}$ tall.

\section{Imperata conferta (J. Presl) Ohwi}

$\bar{o}$ tirau

Widespread Fiji on hillsides and as a weed, but said not to cover extensive areas (FVN 1: 365). ROG 6509, slope SW of Yalobi, uncommon in soil remnants of eroded slope. The similar-looking Imperata cylindrica (L.) P. Beauv. is said to occur in Fiji (Clayton \& Snow 2010: 81). The single, Wayan specimen (cited here) is more like $I$. conferta in its inflorescence, but lacks fertile spikelets. It was identified as I. cylindrica by Gardner \& Pawley (2006: 103).

Lepturus repens (G. Forst.) R. Br.

Widepread on Fiji's coast. No specimen known from Waya; presumed present.

\section{Miscanthus floridulus (Labill.) Warb.}

ex K. Schum. \& Lauterb. ō sina, sina Widespread in Fiji's dry zone grasslands. ROG 6269, Yalobi, to $2 \mathrm{~m}$ tall, abundant on the island's burnt-over hillsides.

Oplismenus compositus (L.) Beauv.

Widespread in Fiji's forests. No specimen known from Waya; seen by $R O G$ in 2017 on forest edges at mid-altitude on Vatunareba. For a treatment of this taxon as three species see Clayton \& Snow (2010: 52)

\section{Paspalum scrobiculatum L.}

Widespread in Fiji, often with Dicranopteris linearis in open infertile (wet or dry) sites.

$R O G$ 11316, inland from Yalobi, at edges of waterfilled pools in rocky outcrops in grassland, and local on dry grassy hillside. Often known, in the Pacific Ocean region, as $P$. orbiculare.

\section{Schizostachyum glaucifolium}

(Rupr.) Munro

bitu dī, ō bitubitu

Widely cultivated in Fiji. ROG 6417, slope above Naseva Beach, at foot of cliffs below peaks, a few groves in open forest, the culms to c. $6 \mathrm{~m}$ tall and $7 \mathrm{~cm}$ $\varnothing$. The status of this bamboo is unclear; some consider it a Fijian endemic, or at least, indigenous there (FVN 1: 294; W. A. Whistler, pers. comm.).

\section{Stenotaphrum micranthum (Desv.) Hubbard}

Widespread on Fiji's coast, perhaps most abundant on the smaller islands. No specimen known from Waya; presumed present.

Thuarea involuta (G. Forst.) R. Br. ex Sm. Widespread on Fiji's coast. ROG 6291, Yalobi, plentiful along stable sandy foreshore.

\subsection{SMILACACEAE}

Smilax vitiensis (Seem.) A. DC. in DC. wā bitubitu Abundant and widespread in Fiji. St John 18025, "wa $m e$ ". ROG 6487, track between Yalobi and Nalauwaki, in dense forest at the peaks W of Nagwa. ROG 6712, towards high point NE of Olo stream, in open ridge forest below summit. Illn: FV t. 93, as Pleiosmilax vitiensis.

\subsection{TACCACEAE (APG IV: Dioscoreaceae)}

Tacca leontopetaloides (L.) Kuntze abia $d \bar{u}$ Widespread in Fiji's coastal forests; perhaps an ancient naturalization. St John 18028.

\subsection{XANTHORRHOEACEAE (APG IV: Asphodelaceae)}

Dianella adenanthera (G. Forst.) R.F. Henderson Widespread in Fiji's drier forests. ROG 6709, towards high point NE of Olo stream, local in open ridge forest, inflorescence notably fragile. Not included in the dry-zone forest species-list of Keppel \& Tuiwawa (2007).

\subsection{ZINGIBERACEAE}

Curcuma longa L.

reregwa

Anciently cultivated in Fiji. St John 18027. ROG 6661, Yalobi, abundant on dry grassy slope, having spread vegetatively downslope from an old garden, apparently able to resist fire.

Zingiber zerumbet (L.) Sm. cegwata Anciently cultivated in Fiji. ROG 6366, near Nagwa, common in open forest, not flowering, no old fruit seen. 


\section{FLORA, PART 3: DICOTYLEDONS}

\subsection{ACANTHACEAE}

Graptophyllum insularum (A. Gray) A.C. Sm. Widespread and abundant in Fiji. St John 18107. $R O G$ 6440, towards the peaks $\mathrm{N}$ of Yalobi, above the gardens, in scrub on ridge crest. $R O G 6710$, towards high point NE of Olo stream, local in open ridge forest, flrs without scent.

\subsection{AIZOACEAE}

Sesuvium portulacastrum (L.) L

Widespread but rather local on Fiji's coast. No specimen known from Waya, Present on Viwa I.: ROG 6771, on coral with Fimbristylis cymosa.

\subsection{AMARANTHACEAE}

\section{*Achyranthes aspera $\mathrm{L}$.} sorisori tavui

Widespread weed in Fiji. ROG 6664, above Olo stream, in scrub below rock face. The Fijian plants belong to var. pubescens (Moq.) C.C. Towns.

Deeringia amaranthoides (Lam.) Merr. tokoi Rather local on Fiji's coast (Waya, Viti Levu and several other islands). ROG 6834, E end of Yalobi, $1.5 \mathrm{~m}$ tall bush, rare in coastal forest; leaves said to be cooked and eaten with octopus [cf. resemblance between animal's tentacles and plant's infructescence].

\subsection{ANACARDIACEAE}

Dracontomelon vitiense Engl.

tawarau

Scattered in Fiji's drier forests, also a village tree. $R O G$ 6530 , slope E of Olo stream, behind the school on dry slope, several $15 \mathrm{~m}$ tall $70 \mathrm{~cm}$ dbh buttressed trees.

Pleiogynium timoriense (DC.) Leenh.

Widespread and abundant in Fiji's drier forests, but apparently rare on Viti Levu. St John 18120. ROG $6458,6466,6474 \& 6480$, slope W of Yalobi, 4-5 m tall, in forest of rocky gully. ROG 6730, above Naseva beach, fruit ripe, skin pinkish crimson, the flesh of similar colour and with a slippery-mealy texture, slightly acid, not sweet but not unpalatable. Although not uncommon on Waya, no local name has been obtained for it.

\section{Rhus taitensis Guillemin} manaw̄ Widespread in Fiji, often abundant in dry scrub and secondary forest. St John 18067, "tawarau". ROG 6420 , above Naseva beach, $6 \mathrm{~m}$ tall $25 \mathrm{~cm}$ dbh, in open forest. $R O G$ 6482, W above Nagwa, $4 \mathrm{~m}$ tall, in scrub on rocky slope. Sometimes known as $R$. simarubifolia. 1ln: USEE 15, Atlas pl. $44 \mathrm{~B}$, as Rhus simarubaefolia.

\section{Semecarpus vitiensis (A. Gray) Engler}

Widespread in Fiji's drier forests. ROG 6435, towards peaks $\mathrm{N}$ of Yalobi, above village's gardens, $12 \mathrm{~m}$ tall 30 $\mathrm{cm} \mathrm{dbh}$, in forest among boulders. Illn: USEE 15, Atlas pl. 43, as Oncocarpus vitiensis.

\subsection{APIACEAE}

Centella asiatica (L.) Urb. totodro Abundant in Fiji. ROG 6363, ridge above Yalobi, occ. at edge of track through grassland.

\subsection{APOCYNACEAE}

Alyxia bracteolosa A. Gray

vono Common in Fiji (Waya and six other high islands), in open drier sites. St John 18117. ROG 6756, peaks E above Yalobi village gardens, local in open ridge forest. At least some of the Wayan plants have been placed in a narrow-leaved variety, var. angustifolia A. Gray, which is said to occur in Fiji (Waya and three other high islands) and Tonga. However, this variety is not maintained by Middleton (2002).

Alyxia stellata (J.R. \& G. Forst.) Roem. \& Schult. Widespread in Fiji, in open drier sites. St John 18052 \& 18161, "vono"; St John 18113, "vundi".

Cerbera manghas $\mathrm{L}$. rewa Widespread in Fiji. ROG 6347, W above Nagwa, trees to $8 \mathrm{~m}$ tall $20 \mathrm{~cm} \mathrm{dbh}$, common in secondary forest, not eaten by goats. ROG 6678, SE slopes of Vatunareba, $4 \mathrm{~m}$ tall $10 \mathrm{~cm} \mathrm{dbh}$, in dry open forest. A colonizer of grassy slopes, the fruits being dropped there by fruit-bats.

\section{Melodinus glaber Turrill} wata

Local in Fiji (Waya and the two largest islands). St John $18053 \mathrm{~A}$, "wata". ROG 6475, slope W of Yalobi, vine to $5 \mathrm{~m}$ high in forest of rocky gully.

Ochrosia oppositifolia (Lam.) K. Schum. vāō Widespread but rather local on Fiji's coasts. The species seems not to grow on Waya but does occur on nearby islets, e.g., ROG 6853, W side of Narara I., trees to $8 \mathrm{~m}$ tall, locally common on rocky slopes just above high-water; this stand said to provide house-posts for the Wayan people. Formerly known as Neisosperma oppositifolium.

\section{Ochrosia vitiensis (Markgraf) Pichon}

Local in Fiji's coastal forests. ROG 6784, gap in ridge $\mathrm{S}$ of Vatunareba summit, one $2 \mathrm{~m}$ tall treelet in dry scrub.

Tabernaemontana pandacaqui Lam. lāqaiqai Common in Fiji's drier light and rocky forests. St John 18149, "totoka". DA 13656. ROG 6305, Olo stream, among rocks in streamside forest; abundant elsewhere 
on the slopes, not eaten by goats. $R O G 6674$, SE slopes of Vatunareba, abundant in dry open places, ripe fruit. Formerly known as Ervatamia obtusiuscula. The first two specimens above are said to belong to a "narrowleaved form", which is found elsewhere in Fiji besides Waya (FVN 4: 98).

\subsection{ARALIACEAE}

\section{Polyscias multijuga}

\section{(A. Gray) Harms}

walanibekwa

Widespread and abundant in Fiji's forest and forest regrowth. St John 18104, "wala nimbergua". ROG 6271, Yalobi, $2.5 \mathrm{~m}$ tall, in scrub and open forest, infl. with female flrs proximally and males distally. Illn: FV t. $18 \& 19$, as Nothopanax multijugum.

\subsection{ASCLEPIADACEAE (APG IV: Apocynaceae)}

Hoya australis $\mathrm{R}$. Br.

Widespread in Fiji, often abundant in dry coastal forest. St John 18164. ROG 6307, Olo stream, above the washing place, uncommon in scrub of gorge. $R O G$ 11323, gully on lower E slope of Vatunareba, epiphytic with Drynaria, flrs fragrant.

Sarcolobus stenophyllus (A. Gray) P.I. Forst. Endemic to Fiji, rare (Waya and northern Vanua Levu). St John 18032, “langaingai”. Illn: FV t. 31, as Gymnema stenophyllum. Formerly known as Leichardtia stenophylla (FVN 4: 114; Forster 1992). Apart from the Wayan collection, only three 20th C. collections are known.

\subsection{ASTERACEAE}

Wollastonia biflora (L.) DC.

Widespread on Fiji's rocky shores. St John 18011 , "thekawa".

\subsection{BALANOPHORACEAE}

Balanophora fungosa J.R. \& G. Forst. varavara Apparently rather local in Fiji's forests. St John 18029. $R O G 6747$, E side of peaks above Waya Levu, in open mesic forest on good soil, also nearby in old Hibiscus tiliaceus scrub on fine talus; male flrs ochre-yellow and pollen white, female flrs brown. The Fijian population belongs to subspecies fungosa, whose members are monoecious.

\subsection{BARRINGTONIACEAE}

(APG IV as Lecythidaceae) Barringtonia asiatica (L.) Kurz

Widespread and abundant on Fiji's coast. No specimen known from Waya; commonly observed, e.g., at Yalobi (ROG 1990s \& 2017).
Barringtonia edulis Seem.

kutuvala

Endemic to Fiji; known from forests on Waya and several other high islands. ROG 6317, E of Olo stream and school, common in relic forest among boulders; fruit green, bat-chewed stones on ground. ROG 6717, loc. supra, trees to $20 \mathrm{~m}$ tall, regenerating in rocky gully.

\subsection{BORAGINACEAE}

Cordia subcordata Lam.

nawanawa

Widespread on Fiji's coast. ROG 6861, Yalobi, near Olo, $7 \mathrm{~m}$ tall $30 \mathrm{~cm}$ dbh trees, locally common in sand among rocks just above HWM, ripe fruit. Illn: FV t. 34 .

\section{Heliotropium foertherianum}

Diane \& Hilger

Widespread on Fiji's coast. No specimen known from Waya; presumed present on Viwa I. Formerly known as Argusia argentea.

\subsection{CAPPARIDACEAE}

\section{Capparis cordifolia Lam.}

Apparently rather local on Fiji's coast. No specimen known from Waya, but there is one from Viwa I.: ROG 6770 , on coral among Casuarina, Pemphis, Guettarda, "bēbē ni vatu".

\subsection{CASUARINACEAE}

Casuarina equisetifolia J. R. \& G. Forst. velau Widespread in Fiji. St John 18155.

\subsection{CELASTRACEAE}

Cassine vitiensis (A.C. Sm.) A.C. Sm.

Endemic to Fiji (Waya, Viti Levu, Ovalau). ROG 6787, towards summit of Vatunareba, $8 \mathrm{~m}$ tall $15 \mathrm{~cm}$ dbh, uncommon in gully forest.

\section{Celastrus richii A. Gray}

Endemic to Fiji, rather uncommon. St John 18053. ROG 6502, slope $\mathrm{W}$ of Yalobi, towards Vatunareba, liane in open forest. ROG 6724, SE slope of Vatunareba, brittle-stemmed liane, common in dry open forest, ripe fruit, each with six seeds.

\subsection{CLUSIACEAE (APG IV: Calophyllaceae)}

Calophyllum inophyllum $\mathrm{L}$. dilo Abundant on Fiji's coast. St John 18903. ROG 6359, Yalobi, at the Sayaba compound, $3 \mathrm{~m}$ tall tree on sand at rear of beach, ripe fruit.

Calophyllum vitiense Turrill damanu

Endemic to Fiji (Waya, Viti Levu, Vanua Levu and several other high islands). ROG 6527, Lekutu, $8 \mathrm{~m}$ tall $15 \mathrm{~cm}$ dbh tree by stream; 6674, loc. cit., $10 \mathrm{~m}$ tall 30 $\mathrm{cm}$ dbh tree, fruit on ground, probably ripe. 
Garcinia pseudoguttifera Seem.

suweru

Widespread in Fiji's forests. St John 18072,

"nambulinomati". ROG 6345, Nagwa, treelet $3 \mathrm{~m}$ tall, locally common in older forest. ROG 6748, E side of peaks above Waya Levu, $4 \mathrm{~m}$ tall, common in forest.

\subsection{COMBRETACEAE}

Terminalia catappa $\mathrm{L}$.

Abundant in Fiji's coastal forests. St John 18094, "tavola". ROG 6278, Olo end of Yalobi, occ. in open forest. $R O G$ 6668, above Olo stream, $10 \mathrm{~m}$ tall, in streamside forest, ripe fruit.

\section{Terminalia litoralis Seem.}

Abundant in Fiji's coastal forests. ROG 6720, Olo stream mouth, $6 \mathrm{~m}$ tall, above mangrove.

\section{Terminalia vitiensis A.C. Sm.}

Endemic to Fiji (Waya and south-central coast of Viti Levu), in dry forest. ROG 6682, SE slopes of Vatunareba, $4 \mathrm{~m}$ tall $10 \mathrm{~cm}$ dbh, uncommon, bark hard, scaly and fissured; flrs lemon-yellow, not scented; fruit unripe, winged along each side. Fig. 3.

\section{Connarus pickeringii A. Gray}

Endemic to Fiji, widespread in drier forests. St John 18130, "wa vatu". ROG 6499, slope W of Yalobi, locally common in forest of rocky gully. Illn: USEE 15, Atlas pl. 45.

\subsection{CONVOLVULACEAE}

Evolvulus alsinoides (L.) L.

Uncommon in Fiji (Waya and Navutu-i-loma), in dry open places. St John 18134,"o-chichi". ROG 13030, E side of Vatunareba, steep open slope, local on thin soil.

\section{Ipomoea littoralis $\mathrm{Bl}$.}

sovivi

Widespread on Fiji's coasts. ROG 11313, slope W of Olo stream, uncommon scrambler in open scrub.

Ipomoea pes-caprae (L.) R. Br. $\quad w \bar{a}$ vulavula Widespread on Fiji's sandy shores. ROG 6444, Naseva beach, on sand-berm above drift-line.

\section{Merremia peltata (L.) Merr.}

veliawa

Widespread in Fiji, especially in disturbed forest. No specimen known from Waya. Abundant in forest at top of Olo Creek (obs. ROG, 2017).

\section{Operculina turpethum (L.) A. Silva Manso}

Widespread in Fiji. ROG 6395, near Waya Levu, vine in scrub, ripe fruit. $R O G 11317, \mathrm{~W}$ of middle part of Olo stream, locally common in rather damp place in scrubby grassland.

\subsection{CUNONIACEAE}

Geissois ternata A. Gray

vuga

Endemic to Fiji; known from drier forests on at least six of the high islands, including Waya. St John 18128. ROG 6376, Lekutu forest between Yalobi and Nalauwaki, $10 \mathrm{~m}$ tall $40 \mathrm{~cm}$ dbh, locally dominant. $R O G 11340$, above mid- part of Olo stream, relic tree in grassland, $8 \mathrm{~m}$ tall.

The St John collection is said to belong to the endemic var. serrata A.C. Sm., which has large, conspicuously toothed leaflets and bristly-hairy stipules (FVN 3: 18). $R O G 6376$ has such stipules, but its leaflets are subentire. Recorded as a dry-zone forest species by Keppel and Tuiwawa (2007), but apparently infrequent at their study sites. Illn: USEE 15, Atlas pl. 86.

\section{Weinmannia vitiensis Seem.}

Endemic to Fiji (Waya, Kadavu, Moala, Taveuni). ROG 6704, towards high point NE of Olo stream, $5 \mathrm{~m}$ tall multi-trunked tree on forest margin. ROG 6789, $4 \mathrm{~m}$ tall bushes, local towards ridge crest.

\subsection{DICHAPETALACEAE}

Dichapetalum vitiense (Seem.) Engl.

Widespread in Fiji but rather local ROG 6433, towards the peaks $\mathrm{N}$ of Yalobi, liane, stems $1 \mathrm{~cm} \varnothing$, in forest. $R O G$ 6750, E side of peaks above Waya Levu, uncommon in open forest.

\subsection{DILLENIACEAE}

Dillenia biflora (A. Gray) Martelli kulukulu Widespread in Fiji's forests (Waya, the three largest islands and Ovalau). ROG 6335, Nagwa, $10 \mathrm{~m}$ tall 20 $\mathrm{cm} \mathrm{dbh}$, locally abundant in light forest, bark falling in large, nearly square, greyish red flakes. Illn: USEE 15, Atlas pl. 1, as Capellia biflora.

\subsection{EBENACEAE}

Diospyros gillespiei (Fosb.) Kostermans kailo Endemic to Fiji. ROG 6675, 6972, SE slopes of Vatunareba, $4 \mathrm{~m}$ tall $10 \mathrm{~cm} \mathrm{dbh}$, common in dry forest up to $\mathrm{c}$. $300 \mathrm{~m}$. The Wayan plant belongs to var. gillespiei, which is known also from four of the larger islands. Fig. 4.

\section{Diospyros major (G. Forst.) Bakh.}

Widespread in Fiji. St John 18167, "bamba". ROG $6516,3 \mathrm{~m}$ tall $10 \mathrm{~cm}$ dbh, seen once in open forest of ridge below rock peaks, flrs male, apparently opening at night and dropping the next day. ROG 6684, SE slopes of Vatunareba, $3 \mathrm{~m}$ tall treelet, occ. in light forest at higher altitudes. ROG 6760, peaks E above Yalobi village gardens, $2 \mathrm{~m}$ tall, common in ridge thickets. Diospyros phlebodes (A.C. Sm.) A.C. Sm. kailo Endemic to Fiji (the several largest islands, and some smaller ones, often near the coast). 


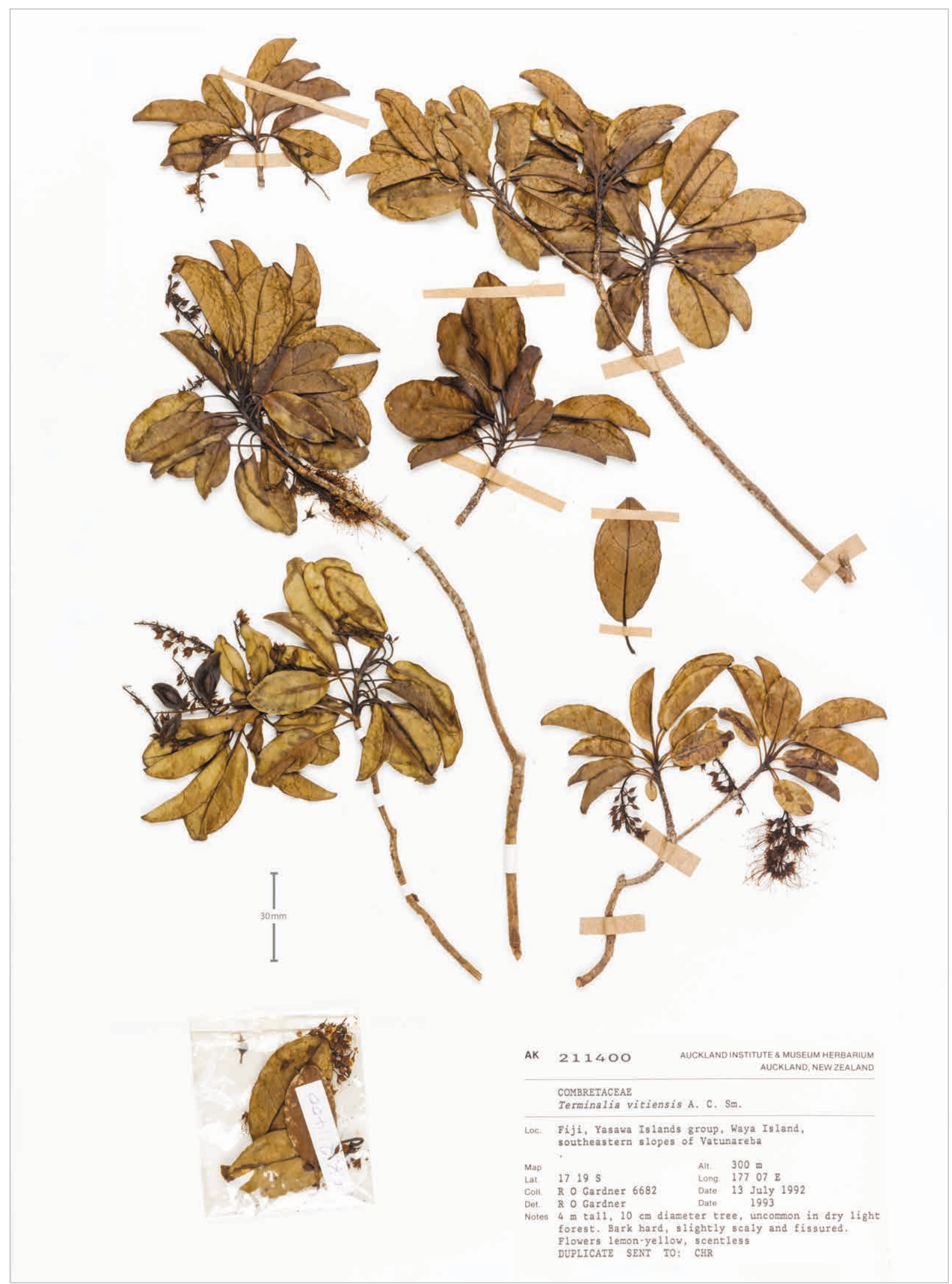

Figure 3. Terminalia vitiensis, AK211400. (c) Auckland Museum CC BY. 


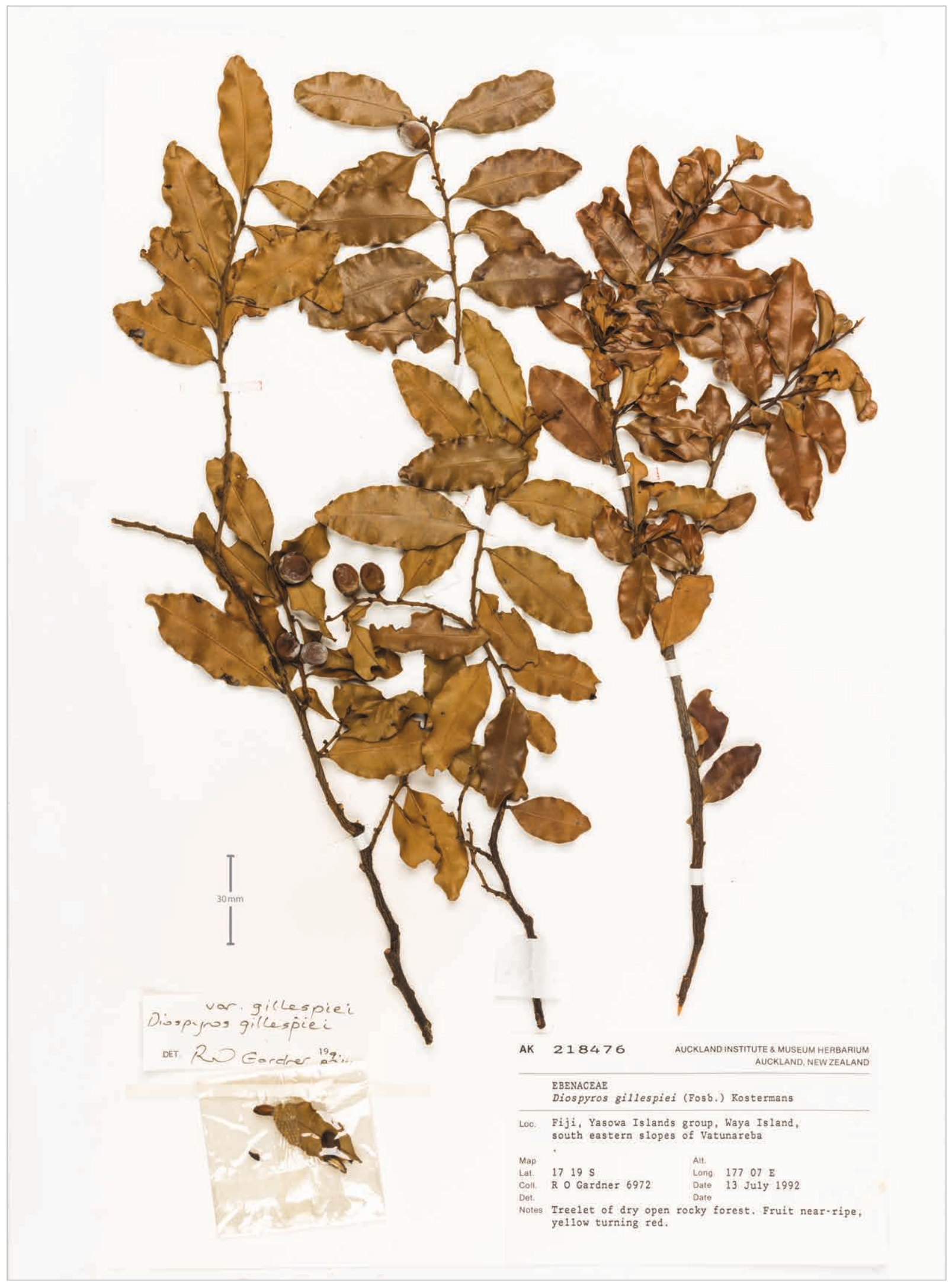

Figure 4. Diospyros gillespiei gillespiei, AK218476. (c) Auckland Museum CC BY. 
ROG 6331, 6430, Yalobi village gardens, trees $2 \mathrm{~m}$ tall, occ. in relic forest on bouldery slope. ROG 6740, 6677, SE slopes of Vatunareba, $4 \mathrm{~m}$ tall, occ. in dry light forest and middle and higher altitudes, fruit ripe. Fig. 5.

\section{Diospyros vitiensis Gillespie}

Endemic to Fiji. St John 18121, "sawira". ROG 6745, -9, E side of peaks above Waya Levu, $3 \mathrm{~m}$ tall treelets in open forest. The Wayan plant belongs to var. longisepala (Gillespie) A.C. Sm., which is also found on Viti Levu and some other high islands.

\subsection{EUPHORBIACEAE}

\section{Acalypha lanceolata Willd.}

Rare in Fiji. No specimen is known from Waya, but the following comes from nearby Naukacuvu I.: ROG 6857, Aug 1992, plant $50 \mathrm{~cm}$ tall, on sandy waste ground around construction site of future resort; presumed to have arisen from the seed-bank. FVN (2: 524, under A. boehmerioides) cites three old collections from Fiji but only one modern one, which supports the idea that the species is an ancient Polynesian weed, unable to compete with more-aggressive newcomers.

\section{Acalypha repanda Muell. Arg.}

karabusi

Widespread in Fiji. St John 18170, "kalambuthi". ROG 6304, Olo, shrub $3 \mathrm{~m}$ tall, common in streamside scrub. ROG 6352, Yalobi, coast E of Olo, $2 \mathrm{~m}$ tall treelets in degraded forest. The Wayan plants belong to var. denudata (Muell. Arg.) A.C. Smith, a small-leaved variety endemic to Fiji and said to be common in the drier zones of Viti Levu and Vanua Levu.

\section{Claoxylon echinospermum Muell. Arg.}

Endemic to Fiji (three highest islands and Waya). ROG 6413, slope above Naseva Beach, $1.5 \mathrm{~m}$ tall treelet in young forest. ROG 6707, towards high point NE of Olo stream, $2 \mathrm{~m}$ tall treelet, local on forest margin.

Codiaeum variegatum (L.) A.H.L. Juss. gwali Widely cultivated (an ancient introduction ?) in Fiji, and often naturalizing. ROG 6741, 6793, E side of peaks above Waya Levu, $3 \mathrm{~m}$ tall, in forest near ridge crest.

Croton metallicus Seem. asiravu

Endemic to Fiji (Waya, Vanua Levu, Kambara). St John 18039, “asirapu”. St John 18119, “asiravu”. ROG 6505 , W side of Vatunareba, near summit, a few $2.5 \mathrm{~m}$ tall bushes, leaves scented of mint and sawdust; orange to crimson when dry. Illn: FV t. 56.

\section{Croton microtiglium Burkill}

Fiji (Waya, Viti Levu and elsewhere). St John 18162, "sobusobu". ROG 6731, SE slope of Vatunareba, $3 \mathrm{~m}$ tall $10 \mathrm{~cm} \mathrm{dbh}$, rare in open forest, perhaps eaten by goats, leaves brittle and hardly fragrant. Illn: FV t. 57, as Croton verreauxii var. storckii.
Euphorbia plumerioides Teijsm. ex Hassk.

Rare on Fiji's rocky coasts (Waya, Viti Levu, and elsewhere). St John 18035, open ledges, $3 \mathrm{~m}$ tall shrub, 600 feet [180 m] a.s.1. "reanitua", medicinal, for constipation. Previously treated as E. fidjiana and said to be endemic to Fiji. Forster (1994: 260) suggests that the plant might not be native to Fiji and that its current sites are mainly where it has been cultivated, e.g., as a garden boundary-marker. Peekel (1984: 320), Henderson \& Hancock (1988: 248) and Hopkins and Menzies (1995: 79) provide ethnobotanical data and illustrations.

Excoecaria agallocha $\mathrm{L}$.

$\operatorname{sinu}$ Widespread on Fiji's coast. St John 18160, "tuku”.

\section{Glochidion concolor Muell. Arg.}

Widespread in Fiji. ROG 6403, Waya Levu gardens, $2 \mathrm{~m}$ tall, in regrowth. $R O G$ 6412, slope above Naseva Beach, crooked treelets $4 \mathrm{~m}$ tall in young forest. $R O G$ 6659,6691 , above Yalobi in thickets on steep slope. The genus is referred by APG IV to the Phyllanthaceae.

Glochidion seemannii Muell. Arg.

Endemic to Fiji (Waya and six other high islands). $R O G$ 6713 , high point NE of Olo stream, $7 \mathrm{~m}$ tall $15 \mathrm{~cm}$ dbh tree at edge of forest. The genus is referred by APG IV to the Phyllanthaceae.

Glochidion vitiense (Muell. Arg.) Gillespie qalo Endemic to Fiji (Waya, and seven other islands). ROG 6476 , slope $\mathrm{W}$ of Yalobi, $3 \mathrm{~m}$ tall tree in forest of rocky gully. The genus is referred by APG IV to the Phyllanthaceae.

Homalanthus nutans (G. Forst.) Guill. Widespread and often abundant in Fiji's secondary forests. St John 18085, "tautau”. ROG 6350, near Nagwa, c. 250 $\mathrm{m}$ alt., treelets to $3 \mathrm{~m}$ tall, dominating some recently burnt slopes, rather infrequent below this altitude.

\section{Macaranga seemannii}

(Muell. Arg.) Muell. Arg. velutu Widespread in Fiji's forests. St John 18074, "velutu". ROG 206377, Yalobi, c. $4 \mathrm{~m}$ tall, cut for firewood. The Wayan plants belong to var. seemannii, which has the range of the species.

Mallotus tiliifolius (B1.) Muell. Arg. aqwata Widespread in Fiji in dry coastal forest. ROG 6258, 6267 , Yalobi village, $4 \mathrm{~m}$ tall, cut for firewood, bark grey-brown, thin and flaky. ROG 6511, slope SW of Yalobi, $4 \mathrm{~m}$ tall $10 \mathrm{~cm} \mathrm{dbh}$, common in open forest of rocky gully, male flrs with a spicy scent.

\section{Phyllanthus virgatus G. Forst.}

Formerly widespread in Fiji (an ancient weed ?), now rare. No specimen is known from Waya, but there is one from elsewhere in the Yasawa Is.: Naviti I., DA 11765. The genus is referred by APG IV to the Phyllanthaceae. 


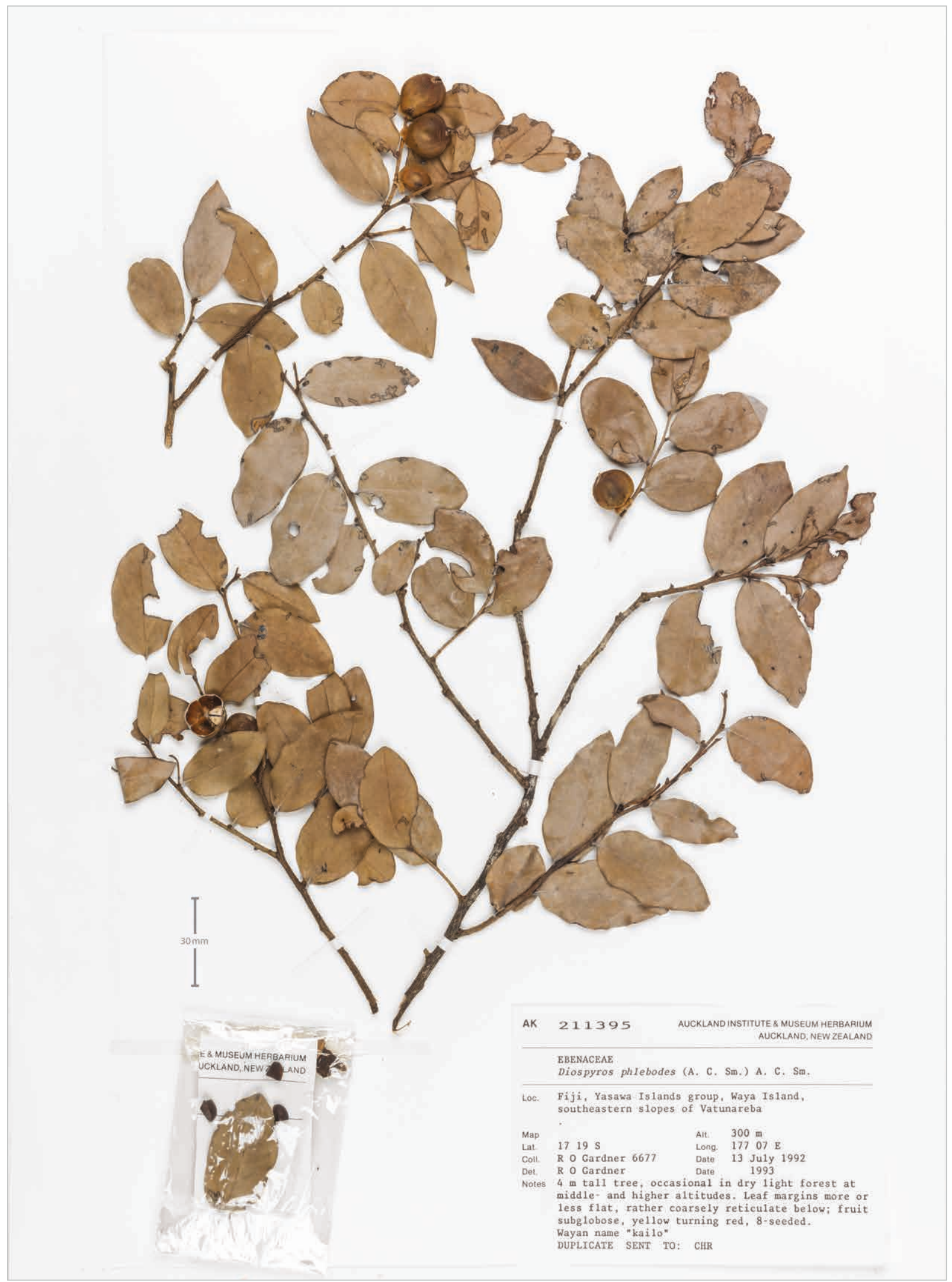

Figure 5. Diospyros phlebodes, AK211395. (c) Auckland Museum CC BY. 
Stillingia pacifica Muell. Arg.

rewarewa

Local on Fiji's coast (Waya, Viti Levu and several other islands). St John 18057, "vasa". DA 13668. ROG 6306 , Olo stream, to $3 \mathrm{~m}$ tall, occ. among rocks in relict streamside forest, abundant elsewhere on dry volcanic slopes, not eaten by goats. $R O G$ 6443, slope above Naseva beach, $3 \mathrm{~m}$ tall, locally dominant on rocky ground, fruit ripe, "rewarewa". Also known as S. lineata (Lam.) Muell. Arg. subspecies pacifica (Muell. Arg.) Steenis.

\subsection{FLACOURTIACEAE (APG IV: Salicaceae)}

Casearia longifolia A.C. Sm.

Endemic to Fiji, dry forest (Waya, Viti Levu). St John 18111, "bombongua". DA 13667. ROG 6405, gardens of Waya Levu village, $3 \mathrm{~m}$ tall in regrowth. ROG 6692, -3, SE slopes of Vatunareba, $3 \mathrm{~m}$ tall, common in dry forest.

\section{Erythrospermum acuminatissimum}

(A. Gray) A.C. Sm.

Widespread in Fiji. St John 18073, "dakariwai". ROG 6495, slope $\mathrm{W}$ of Yalobi, $2 \mathrm{~m}$ tall, occ. in forest of rocky gully, ripe fruit. $R O G 6697$, SE slopes of Vatunareba, $6 \mathrm{~m}$ tall, common here in mid-altitude forest, flrs rose-scented. The genus is referred by APG IV to the Achariaceae.

Flacourtia subintegra A.C. Sm.

Endemic to Fiji ( Waya, Viti Levu Vanua Levu, Ovalau and Vanua Mbalavu). St John 18166 (US), Nakawa Gulch, upper woods, tree $8 \mathrm{~m}$ tall $4 \mathrm{~cm}$ dbh, "ngalo". $R O G$ 11332, foot of rocky slope $\mathrm{W}$ of Yalobi, $10 \mathrm{~m}$ tall $20 \mathrm{~cm}$ dbh sprawling male tree, flrs honey-scented.

\section{Homalium vitiense Benth.}

tura

Endemic to Fiji, rather infrequent, mainly on the two largest islands and Waya. St John 18146. ROG 6421, slope above Naseva Beach, crooked tree $3 \mathrm{~m}$ tall $25 \mathrm{~cm}$ basal $\varnothing$ in scrub on rocky slope. $R O G 6888$, SE slope of Vatunareba, $5 \mathrm{~m}$ tall $15 \mathrm{~cm}$ dbh tree, common in dry open scrub.

Xylosma simulans A.C. Sm.

Fiji (Waya and several other islands but not Viti Levu). St John 18166, "ngalo". ROG 6673, SE slopes of Vatunareba, $3 \mathrm{~m}$ tall, local in dry open scrub.

\subsection{GESNERIACEAE}

\section{Cyrtandra anthropophagorum Seem.}

Endemic to Fiji. $R O G$ 6851, E side of peaks above Waya Levu, $1 \mathrm{~m}$ tall plants in open place in thicket near ridge crest, not seen elsewhere. This is the most widespread and abundant Cyrtandra species in Fiji, presumably because it tolerates relatively dry sites.

\subsection{GOODENIACEAE}

Scaevola sericea Vahl

Widespread on Fiji's coast. ROG 6535, E of Olo stream mouth, $2 \mathrm{~m}$ tall, at rear of beach. Often known as $S$. taccada.

\subsection{GYROCARPACEAE (APG IV: Hernandiaceae)}

Gyrocarpus americanus Jacq. toca, toutou Widespread in Fiji's drier coastal forests. St John 18110, "toto". St John 18151, "toto". ROG 6362, Yalobi, ridge above Sayaba compound, $10 \mathrm{~m}$ tall $50 \mathrm{~cm}$ $\mathrm{dbh}$, in relic forest among boulders. $R O G$ 6827, ridge E of Yalobi, on rocky grassy hillside; crushed leaves smell of beans.

\subsection{HERNANDIACEAE}

Hernandia nymphaeifolia (Presl) Kubitzi buevu Widespread on Fiji's coast. St John 18090, "mbuebu". ROG 6283, Yalobi, $8 \mathrm{~m}$ tall tree on sandy low terrace at rear of beach, flrs with a spicy fragrance.

\subsection{HIPPOCRATEACEAE}

Salacia vitiensis A.C. Sm.

Endemic to Fiji, rather uncommon (Waya, Viti Levu, Vanua Levu, Vanua Mbalavu). ROG 6687, SE slopes of Vatunareba, liane in dry forest. $R O G 6868$, loc. cit., in open place in gully forest.

\subsection{ICACINACEAE (APG IV: Cardiopteridaceae)}

\section{Citronella vitiensis R. Howard}

Endemic to Fiji (Waya, Viti Levu, Ovalau, Vanua Levu), perhaps usually in drier forests. ROG 6744, E side of peaks above Waya Levu, $3 \mathrm{~m}$ tall tree in ridge thicket, fruit green to purple.

\subsection{LAMIACEAE}

Leucas decemdentata (Willd.) Sm.

Rather local in Fiji. ROG 6772, Nagwa peaks (E above gardens in valley NW of Yalobi), on rock ledge in the open, not seen elsewhere. Formerly widespread in open dry sites, now losing to competition from more-aggressive weeds (cf. Acalypha lanceolata, Mollugo pentaphylla, Phyllanthus virgatus, and Plectranthus forsteri).

\section{Plectranthus forsteri Benth.}

Uncommon in Fiji. St John 18109, "mbambaranga". ROG 6890, near Vatunareba summit, on rock ledge in open scrub, not seen elsewhere, ripe fruit. Apparently another of Fiji's pre-European weeds; see the preceding entry. Illn: FV t. 47.

\subsection{LAURACEAE}

Cassytha filiformis L. walawala Abundant on Fiji's coast. St John 18097, Wailevu Creek. ROG 6654, Olo stream, in rocky streamside hibiscus scrub. 


\subsection{LAURACEAE}

Litsea vitiana (Meissn.) Benth. \& Hook. f.

Endemic to Fiji (Waya and the three largest islands, and others). St John 18054, "tarutaru ni lolo". ROG 6497, slope W of Yalobi, $15 \mathrm{~m}$ tall $30 \mathrm{~cm}$ dbh, rare in forest of rocky gully. $R O G 6839$, high point NE of Olo stream, 8 $\mathrm{m}$ tall $25 \mathrm{~cm} \mathrm{dbh}$, in open forest of ridge crest.

Illn: FV t. 50, as Tetranthera vitiana.

\subsection{LEEACEAE}

\section{Leea indica (Burm. f.) Merr.}

Widespread in Fiji. ROG 6751, peaks above Waya

Levu, uncommon in open forest on talus.

\subsection{LEGUMINOSAE}

Abrus precatorius L.

lele

Widespread on Fiji's coast. St John 18030. ROG 6400, near Waya Levu village, occ. in streamside scrub.

\section{Acacia simplex (Sparrman) Pedley \\ Widespread on Fiji's coast. ROG 11295, above \\ Vunasinu Point (between village and Olo stream mouth), several trees in secondary forest on dry slope.}

\section{Caesalpinia bonduc}

\section{(L.) Roxb. kai lalālau, qalausori}

Widespread in Fiji. ROG 6408, Yalobi, occ. climber in open bush and under Cocos on sand.

\section{Caesalpinia major}

(Medik.) Dandy \& Exell kai lalālau, qalausori Quite widespread in Fiji but apparently not known from Viti Levu. ROG 6446, Naseva Beach, at edge of coastal scrub. $R O G$ 6510, slope SW of Yalobi, occ. in open forest of rocky gully.

\section{Canavalia cathartica Thou.}

Widespread in Fiji's lowland scrub. St John 18078, Wailevu Creek, "wati koori" [wa tikuri].

\section{Canavalia rosea (Sw.) DC.}

rautolu

Widespread on Fiji's coast. ROG 6448, Naseva Beach, in sandy waste at coastal fringe.

\section{Canavalia sericea A. Gray}

Widespread on Fiji's coast. ROG 6814, 11333, Naseva Beach, occ. on sand just above HWM.

Cynometra insularis A.C. Sm. namo

Endemic to Fiji (Waya and five other high islands), in dry forest. St John 18055, "cibicibi". ROG 6349, Nagwa, $12 \mathrm{~m}$ tall $30 \mathrm{~cm}$ dbh, locally common in older forest. $R O G$ 6655, Olo stream, $6 \mathrm{~m}$ tall, in rocky streamside scrub. ROG 6837 , towards high point above Olo stream, in open forest on rocky slope, flrs with a slightly sour odour.
Dendrolobium umbellatum (L.) Benth. seuseutavē Widespread in Fiji, in dry coastal scrub. St John 18086 , "seuseutavei". ROG 6250, Yalobi, $4 \mathrm{~m}$ tall bushes in dryish scrub, common only where goats cannot get to. $R O G$ 6733, towards summit of Vatunareba, treelets in Dodonaea-Decaspermum scrub.

Derris trifoliata Lour. tuva $d u$

Widespread and abundant on Fiji's coast. ROG 6275, Yalobi, common climber in open bush.

Entada phaseoloides (L.) Merr. $\quad$ wā qiri, wā tiqiri Widespread in Fiji. ROG 6387, between Yalobi and Nalauwaki, climber in secondary forest.

\section{Erythrina variegata $\mathrm{L}$.}

rara

Widespread in Fiji's drier coastal forests. St John 18091. Weiner 254, Yalobi. ROG 6316, E of Olo stream, a few trees $12 \mathrm{~m}$ tall $60 \mathrm{~cm}$ dbh in open forest among boulders, small spines of branchlets \pm proximal on growth flushes, fruit ripe. Seemann (FV: 60) noted that the Fijians coordinated the time of planting of the yam Dioscorea alata with the flowering of the rara.

Inocarpus fagifer (Parkinson) Fosberg $i v i$

Anciently cultivated in Fiji, often naturalized near the coast, $R O G$ 11329, rear of mangrove E of Yalobi village, a few out-of-season flrs, scented as violets.

Intsia bijuga (Colebr.) Kuntze vesi, vesi $d \bar{u}$ Widespread and abundant in Fiji's drier coastal forests.

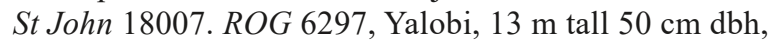
in open bush at foot of hillside.

Illn: USEE 15, Atlas pl. 51, as Afzelia bijuga.

Kingiodendron platycarpum B.L. Burtt namo Endemic to Fiji (Waya and five other high islands). $R O G$ 6532, slope W of Yalobi, towards Naseva beach, $8 \mathrm{~m}$ tall $30 \mathrm{~cm} \mathrm{dbh}$, in forest along bouldery gully, fruit green turning to brown, perhaps nearly ripe. ROG 6722, SE slope of Vatunareba, $10 \mathrm{~m}$ tall $25 \mathrm{~cm} \mathrm{dbh}$, common in open dry forest.

Maniltoa grandiflora (A. Gray) Scheffer namo Widespread in Fiji's drier forests. ROG 6736, SE slope of Vatunareba, $3 \mathrm{~m}$ tall treelet in gully forest. $R O G$ 6746, 6800, E side of peaks above Waya Levu, $3 \mathrm{~m}$ tall, in ridge-crest thicket.

Illn: USEE 15, Atlas pl. 52, as Cynometra grandiflora

\section{Milletia pinnata (L.) Panigrahi}

vesi, vesi wai Widespread in Fiji's coastal forests. St John 18089, "tosinga". ROG 6353, coast E of Olo end of Yalobi, 10 $\mathrm{m}$ tall $40 \mathrm{~cm}$ dbh sprawling tree, fruit ripe. Formerly known as Pongamia pinnata.

Mucuna gigantea (Willd.) DC. kori, tikori Widespread in Fiji's forests. St John 18092, "wa tikoori". ROG 6414, slope above Naseva Beach. ROG 6528, 6529, Olo stream, in Hibiscus tiliaceus scrub, ripe fruit. 


\section{Ormocarpum orientale (Spreng.) Merr.}

Rare on Fiji's dry coasts (Waya, Ovalau, Matuku). ROG 6762, SE slope of Vatunareba, two small treelets in dry open scrub; seen just once elsewhere. The two non-Wayan collections from Fiji are 19th C. ones. The species is also known as $O$. cochinchinense (Lour.) Merr.

\section{Pueraria lobata (Willd.) Ohwi} $a k a$

Widespread in Fiji's dry scrubby hillsides, perhaps after cultivation as a famine-food. ROG 6263, Yalobi, common in dry open places, sometimes initially dominant after grassland fires.

\section{Schleinitzia insularum (Guillemin) Burkart}

Local on Fiji's drier coasts (Waya, Vanua Levu and several other islands). ROG 11326, near S end of Naseva beach, several old trees at one place on coral rock and sand, to $4 \mathrm{~m}$ tall $15 \mathrm{~cm} \mathrm{dbh}$, not regenerating here (the bush frontage being dominated by Leucaena leucocephala).

\section{Serianthes vitiensis}
A. Gray
sē agoago, kaimocemoce

Endemic to Fiji, rare (Waya; two collections from Vanua Levu). ROG 6872, N side of Lekutu, $15 \mathrm{~m}$ tall $80 \mathrm{~cm}$ dbh short-boled tree in forest among rocks. $R O G$ $6810, R O G$ 6825, summit of second peak E of top of gardens in valley NW of Yalobi, in Geissois forest. The related $S$. melanesica is listed as a dry-forest species by Keppel \& Tuiwawa (2007: 563). Fig. 6

Tephrosia purpurea (L.) Pers.

Widespread on Fiji's coast. St John 18137 ,

"rhausenge". ROG 6398, Waya Levu, occ. in gravel berm at beach rear, ripe fruit.

\section{Vigna marina (Burm.) Merr.}

Widespread on Fiji's coast. ROG 6281, Yalobi, at Olo, prostrate vine at beach rear.

\subsection{LOGANIACEAE}

Geniostoma vitiense Gilg \& Benedict buibuitā Widespread and abundant in Fiji's forests. St John 18018, "boiboinda". ROG 6365, Nagwa, $4 \mathrm{~m}$ tall treelet in older secondary forest. $R O G$ 6506, slope $\mathrm{W}$ of Yalobi towards Vatunareba, $8 \mathrm{~m}$ tall $20 \mathrm{~cm}$ dbh, occ. in forest of rocky gully, ripe fruit. ROG 6841, towards high point north of Olo stream, $4 \mathrm{~m}$ tall treelet in open forest, flrs pale green, with a faecal odour.

\subsection{LYTHRACEAE}

\section{Pemphis acidula J.R. \& G. Forst.}

Rather local in Fiji, on coral shores. No specimen is known from Waya, but the species occurs on Viwa I. (ROG obs., July 1991).

\subsection{MALPIGIACEAE}

\section{Hiptage myrtifolia A. Gray}

Endemic to Fiji (Waya, the larger high islands but not Taveuni, and some smaller islands). ROG 6534, slope $\mathrm{W}$ of Yalobi, towards Nasewa Beach, liane to $4 \mathrm{~m}$ high in forest of bouldery gully. ROG 6737, SE slope of Vatunareba, occ. in dry forest. Illn: USEE 15, Atlas pl. 21.

\subsection{MALVACEAE}

Hibiscus tiliaceus $\mathrm{L}$. rea, vau Widespread in Fiji. ROG 6257, Yalobi, shrub $4 \mathrm{~m}$ tall, common throughout the island.

\section{Sida rhombifolia $\mathrm{L}$.}

Widespread in Fiji, a weed of dry open places. ROG 6287, nr Yalobi school, common in grassy waste, ripe fruit.

Thespesia populnea (L.) Solander wiriwiri Widespread in Fiji's coastal forests. ROG 6276, Yalobi, common at beach rear, ripe fruit.

Urena lobata L. qatima Widespread in Fiji in dry open places (an ancient introduction ?), but perhaps declining in frequency. ROG 6426, above Naseva Beach, $1 \mathrm{~m}$ tall singlestemmed bushes, local in open forest, ripe fruit.

\subsection{MELASTOMATACEAE}

Medinilla ovalifolia (A. Gray) A.C. Sm.

Endemic to Fiji (Waya, Viti Levu, Vanua Levu, Ovalau). ROG 6848, E side of peaks above Waya Levu, rare (only two plants seen), epiphytic in low ridge-crest forest.

\section{Memecyclon vitiense A. Gray}

Widespread in Fiji's forests. St John 18044. ROG 6461, slope $\mathrm{W}$ of Yalobi, $3 \mathrm{~m}$ tall $5 \mathrm{~cm}$ dbh, in forest of rocky gully. ROG 6671, in forest high on SE slopes of Vatunareba, locally common.

\subsection{MELIACEAE}

Aglaia vitiensis A.C. Sm.

Endemic to Fiji. St John 18165, “boiboi”. ROG 6703, SE slopes of Vatunareba, $2 \mathrm{~m}$ tall treelet, ripe fruit. $R O G 6685$, loc. cit., occ. in dry light forest at middle and higher altitudes. The Wayan plant belongs to var. minor A.C. Sm., which is known from six of the larger islands.

\section{Dysoxylum mollissimum Miq.}

Widespread, abundant in Fiji's forests. ROG 6429, near peaks $\mathrm{N}$ of valley above Yalobi village's garden valley, $12 \mathrm{~m}$ tall $30 \mathrm{~cm} \mathrm{dbh}$, in forest among boulders. Illn: USEE 15, Atlas pl. 20, as Didymochiton richii. Until recently, known as Dysoxylum richii. 


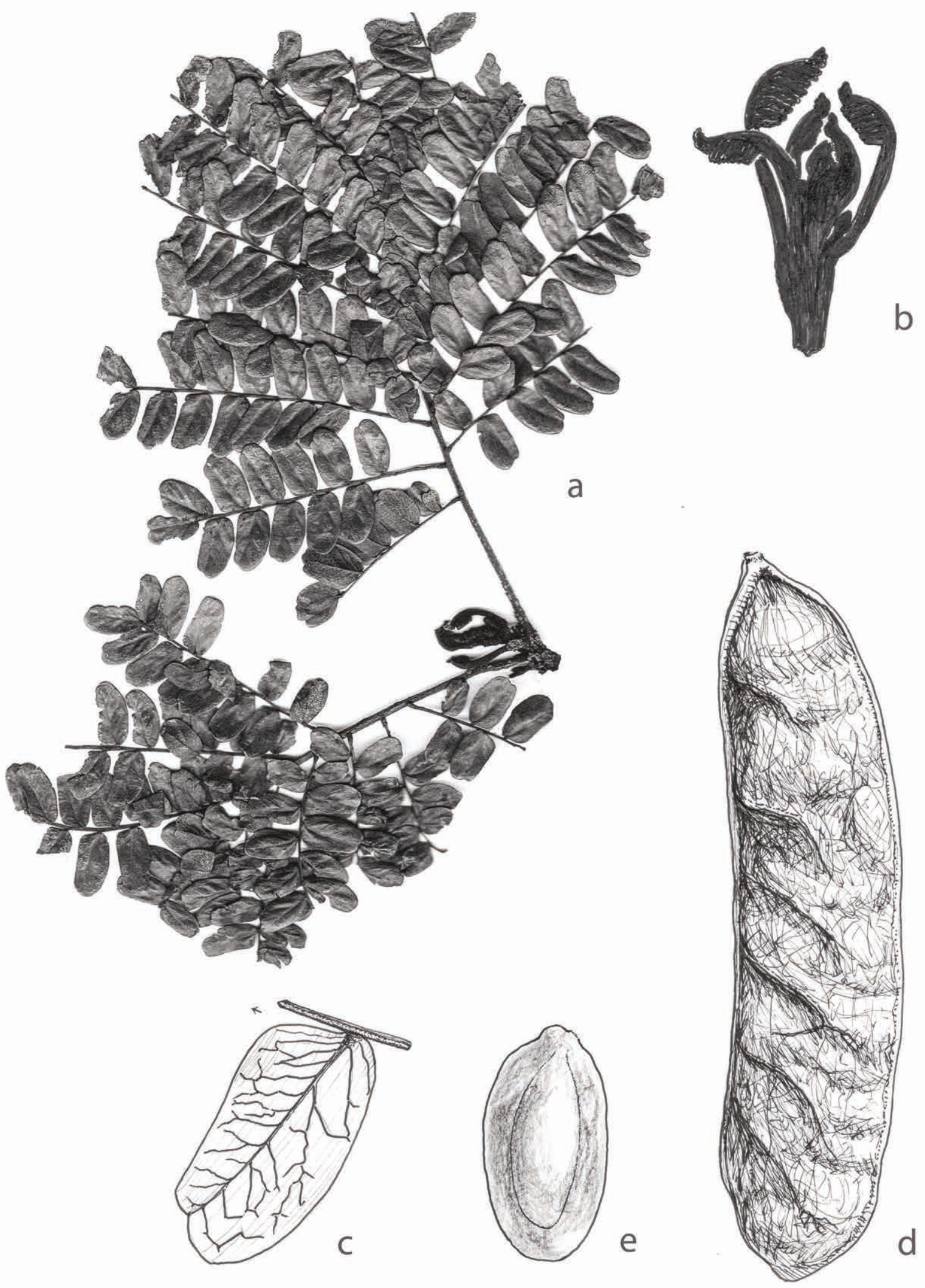

Figure 6. Serianthes vitiensis. a, Leaf [scan, Iflts $1.5 \mathrm{~cm}$ long]; $b$, Shoot apex [photo, image $3 \mathrm{~cm}$ long]; $c$, Leaflet (abaxial), showing prominent nerves [ Iflt $1.5 \mathrm{~cm}$ long]; $d$, Fruit-pod, its seed-bearing edge on left [pod $5 \mathrm{~cm}$ wide]; e, Seed in face view [seed $1.35 \mathrm{~cm}$ long]. a-c from AK 213349, Waya; $d$, e from AK 213395,Waya. 


\section{Dysoxylum seemannii Gillespie}

Endemic to Fiji, apparently widespread in drier forests. $R O G$ 6310, Olo stream, $2 \mathrm{~m}$ tall, occ. among rocks in relic forest, cut bark without odour. ROG 6701, S side of Vatunareba, $3 \mathrm{~m}$ tall, local in forest of old talus slope, near-ripe fruit. $R O G 6821$, loc. cit.

\section{Vavaea amicorum Benth.}

Widespread in Fiji's forests. ROG 6457, $5 \mathrm{~m}$ tall $10 \mathrm{~cm}$ $\mathrm{dbh}$, in forest of rocky gully. ROG 6679, SE slopes of Vatunareba, occ. in dry light forest, ripe fruit. This fruit is said to be the favorite food of the Fijian crested iguana (Morrison et al. 2009). Illn: USEE 15, Atlas pl. 16 B.

\section{Xylocarpus granatum Koenig leqileqi \\ Widespread on Fiji's coast. ROG 6286, Yalobi, at the Olo stream lagoon, $3 \mathrm{~m}$ tall, infrequent.}

\subsection{MOLLUGINACEAE}

\section{Mollugo pentaphylla $\mathrm{L}$.}

Uncommon (an ancient introduction ?) in Fiji in dry places; ROG 6729, SE slopes of Vatunareba, on shallow soil on lava.Other than this Wayan record only one 20th C. collection, from Viti Levu, seems to have been made of this plant.

\subsection{MORACEAE}

Ficus barclayana (Miq.) Summerhayes masimasi Endemic to Fiji (Waya, the three largest islands, and elsewhere). St John 18096, “masimasi”. ROG 6381, Yalobi, $2.5 \mathrm{~m}$ tall treelet in scrub at foot of hillside, hacked-about to provide goat fodder. ROG 6384, Yalobi to Nalauwaki track, in scrub at stream S of Koroimatalevu peak (high point $\mathrm{S}$ of Lekutu), $4 \mathrm{~m}$ tall, ripe fruit. $R O G$ 11298, -9, Yalobi to Natawa track, common in degraded tall coastal forest. ROG 6658, Olo stream, $2.5 \mathrm{~m}$ tall $5 \mathrm{~cm} \mathrm{dbh}$, in dry streamside forest, the figs soft, white, with wasps exiting apically. $R O G$ 6807, peaks E above top of Yalobi's garden-valley, $4 \mathrm{~m}$ tall tree in scrub on steep slope, the figs ripe, dark and soft, with seeds. Illn: FV t. 66, as F. barclayi.

\section{Ficus masonii Horne ex Baker}

Endemic to Fiji (Waya, the three largest islands, and elsewhere). St John 18040, Naruarua Gulch, "masimasi". ROG 6767, Viwa I., $4 \mathrm{~m}$ tall $10 \mathrm{~cm}$ dbh tree in garden; supposedly brought from Likuliku on Waya I., to provide a famine food.

Ficus obliqua G. Forst.

Widespread in Fiji's drier forests. St John 18037, "bak". ROG 6415, rocky slope above Naseva, $12 \mathrm{~m}$ tall banyan, ripe fruit. The record of $F$. prolixa from Waya (Gardner \& Pawley 2006: 99) is probably based on a sighting of $F$. obliqua; no Wayan specimen of $F$. prolixa is known, and the species is infrequent in Fiji. Illn: FV t. 68, excl. fig. 8, which is Ficus prolixa (FVN 2: 174).
Ficus pritchardii Seem.

$a a w a$

Endemic to Fiji, abundant on many of the larger islands. St John 18013, "kamba". ROG 6716, towards high point NE of Olo stream, $8 \mathrm{~m}$ tall, $15 \mathrm{~cm}$ dbh. $R O G$ 6757 , peaks $\mathrm{E}$ above gardens in valley NW of Yalobi, $10 \mathrm{~m}$ tall $20 \mathrm{~cm}$ dbh, common in forest with Dillenia and Geissois, figs turning from greenish pink to red and soft and wasps in them now escaping through apex. Illn: FV t. 70.

Ficus tinctoria G. Forst. $a a w a$

Widespread in Fiji's coastal forests. St John 18041, Naruarua Gulch, "mbaka”. ROG 6493, slope W of Yalobi, $4 \mathrm{~m}$ tall tree in forest of rocky gully, uncommon. Illn: FV t. 63.

Ficus vitiensis Seem.

$k a b a$

Endemic to Fiji, widespread and often abundant. $R O G$ 6270 , Yalobi, above the Sayaba compound, $4 \mathrm{~m}$ tall 10 $\mathrm{cm}$ dbh tree on dry hillside.

Trophis scandens (Lour.) Hook. \& Arn. wata Rather local in Fiji (Waya, Mamanuca Is., the three largest islands). ROG 6462, slope $\mathrm{W}$ of Yalobi, brittlestemmed liane in forest of rocky gully. Formerly known as Malaisia scandens.

\subsection{MYRISTICACEAE}

\section{Myristica chartacea Gillespie}

kaidam

Endemic to Fiji (Waya, the two largest high islands and several others). ROG 6496, slope $\mathrm{W}$ of Yalobi, single $6 \mathrm{~m}$ tall tree in forest of rocky gully, ripe fruit. $R O G$ 6698, SE slopes of Vatunareba, uncommon in mid-altitude gully forest.

\subsection{MYRSINACEAE (APG IV Primulaceae)}

\section{Embelia deivanuae R.O. Gardner}

Endemic to Fiji, so far known only from Waya (Gardner 1997: 487). ROG 6811, on the peak east above top of Yalobi village gardens. Not rediscovered in 2017.

Maesa persicifolia A. Gray butabuta

Endemic to Fiji (Yasawa Is., Viti Levu and Vanua Levu). St John 18010. ROG 6249, Yalobi, $2 \mathrm{~m}$ tall, common in dry scrub, ripe fruit. ROG 6504, slope $\mathrm{W}$ of Yalobi, towards Vatunareba, $2 \mathrm{~m}$ tall, in open forest, ripe fruit. $R O G 6656$, Olo stream, $1 \mathrm{~m}$ tall shrub on scrubby dry slope.

\section{Myrsine myricifolia A. Gray}

Widespread and abundant in Fiji's forests. St John 18159, "becebece". ROG 6439, towards the peaks $\mathrm{N}$ of Yalobi above the village's gardens, rare, rock cliffs. $R O G$ 6670, SE slopes of Vatunareba, locally common in dry forest. Sometimes known as Rapanea myricifolia. 


\subsection{MYRTACEAE}

Decaspermum vitiense (A. Gray) Niedenzu nuqa Endemic to Fiji, common in light dry forest. $R O G$ 6469 , Lekutu forest, sprouting from cut $10 \mathrm{~cm} \varnothing$ stump in aqona garden, flrs fragrant. Illn: USEE 15, Atlas pl. 60 B, C, D, as Nelitris vitiensis and N. fruticosa.

Eugenia reinwardtiana (Bl.) DC. $q \bar{e}$ ni koro Abundant on Fiji's coast. ROG 6832, E end of Yalobi coastal frontage, $2 \mathrm{~m}$ tall bushes, local in coastal forest remnant on clay slope. Sometimes known as Jossinia reinwardtiana or Eugenia rariflora. Illn: USEE 15, Atlas pl. 60 A, as E. rariflora.

\section{Metrosideros collina (J.R. \& G. Forst.) A. Gray Widespread in Fiji's rocky forests. St John 18156, "sekula". ROG 6735, SE slope of Vatunareba, $5 \mathrm{~m}$ tall bushes at top of rock face, uncommon. The Wayan plant has been identified as belonging to var. villosa (L.f.) A. Gray, which appears to have the range of the species, excepting Hawaii. Illn: USEE 15, Atlas pl. 68.}

Syzygium corynocarpum (A. Gray) C. Muell. ulalo Widespread in Fiji's forests. St John18043. ROG 6503, slope W of Yalobi towards Vatunareba, $300 \mathrm{~m}, 5 \mathrm{~m}$ tall $10 \mathrm{~cm} \mathrm{dbh}$, local in open forest in gap between the peaks. Illn: USEE 15, Atlas pl. 64, as Eugenia corynocarpa.

\section{Syzygium gillespiei Merr. \& Perry}

Endemic to Fiji (Waya and also, though rather infrequently, on the two largest islands). $R O G 6850$, E side of peaks above Waya Levu, $4 \mathrm{~m}$ tall $5 \mathrm{~cm} \mathrm{dbh}$ treelets, local in ridge-crest thicket.

\section{Syzygium gracilipes (A. Gray) Merr. \& Perry} Endemic to Fiji, as a widespread forest-understorey tree, St John 18172, Olo Creek, "naaaloalo [na aloalo]”. Illn: FV t. 15, as Eugenia gracilipes.

\section{Syzygium malaccense (L.) Merr. \& Perry kavika} Anciently cultivated in Fiji. St John 18124.

\section{Syzygium neurocalyx}

\section{(A. Gray) Christophersen}

Widespread in Fiji's forests, and often cultivated for its scented fruit. ROG 6464, Yalobi, $2 \mathrm{~m}$ tall tree by main entrance to chief's bure. Illn: USEE 15, Atlas pl. 59, as Eugenia neurocalyx.

\section{Syzygium richii}

\section{(A. Gray) Merrill \& Perry}

dakadaka

Widespread in Fiji's coastal forests. ROG 6779, Olo, old $4 \mathrm{~m}$ tall tree on beach frontage; also $\mathrm{nr}$ mangrove here, otherwise not seen on island. Illn: USEE 15, Atlas pl. 58, as Eugenia richii.
Syzygium rubescens (A. Gray) C. Muell.

Endemic to Fiji (Waya, the two largest islands, and Ovalau). ROG 6459, slope $\mathrm{W}$ of Yalobi, $7 \mathrm{~m}$ tall $40 \mathrm{~cm}$ $\mathrm{dbh}$, in forest of rocky gully. ROG 6477, slope W of Yalobi, $5 \mathrm{~m}$ tall $20 \mathrm{~cm}$ dbh, in rocky gully forest. Listed as a dry-zone forest species by Keppel \& Tuiwawa (2007: 560).

Illn: USEE 15, Atlas pl. 63, as Eugenia rubescens.

Syzygium seemannianum Merr. \& Perry asiasi Endemic to Fiji (Waya and five other high islands); a rheophyte, often abundant in its streamside habitat. ROG 6308, 6667, 6870 [with ripe fruit], above Olo stream near Yalobi, to c. $10 \mathrm{~m}$ tall $50 \mathrm{~cm}$ dbh, common at forested stream edge among boulders. The suggestion (Gardner \& Pawley 2006: 99) that ROG 6308 might represent $S$. curvistylum is wrong.

\subsection{NYCTAGINACEAE}

\section{Boerhavia glabrata $\mathrm{Bl}$.}

Local on Fiji's coast. ROG 6390, Olo, occasional at rear of sandy beach. The names $B$. diffusa or $B$. repens (in the broadest sense) might apply to this plant.

Pisonia grandis $\mathrm{R}$. Br.

koakoa Local in Fiji 's coastal forests (Waya, Kadavu, Vanua Levu, Nayambo). ROG 6875, top of gardens in valley $\mathrm{NW}$ of Yalobi, a single tree $15 \mathrm{~m}$ tall $80 \mathrm{~cm}$ dbh on rocky slope, trunk stout and cylindrical, with smooth pale bark and rather sappy wood; said to be rare on the island.

\subsection{OLACACEAE}

\section{Ximenia americana $\mathrm{L}$.}

Widespread on Fiji's coast. ROG 6781, rocky coast near Vanuaseva, a single $1 \mathrm{~m}$ tall bush, "soni" given as possible Wayan name.

\subsection{OLEACEAE}

Chionanthus vitiensis (Seem.) A.C. Sm.

Fiji (Waya and four other high islands). ROG 6686, SE slopes of Vatunareba, $4 \mathrm{~m}$ tall, occ. in light dry forest at middle and higher altitudes, fruit nearly ripe.

Jasminum didymum G. Forst.

rautolu Widespread in Fiji, in dry open forest. St John 18036, Naruarua Gulch, "nunganunga"; St John 18103, Nagua, "rautolu". ROG 6808, central peaks above Yalobi village gardens, climber in open fire-damaged forest on dry ridge, uncommon; fruit mostly not quite ripe. The Wayan specimens of St John here have been identified (FVN 4: 127) as Jasminum degeneri Kobuski, a taxon so far known only from Waya and coastal northern Viti Levu. This seems to be just a xerophytic form of $J$. didymum. 


\subsection{PEPEROMIACEAE (APG IV: Piperaceae)}

\section{Peperomia blanda Kunth}

Widespread in Fiji. St John 18108, "tangatanga". ROG 6452, slope W of Yalobi, $20 \mathrm{~cm}$ tall juveniles, rare on shady rocky ledges in forest, only near the sea and where goats cannot get to; no fertile plants seen. The Wayan plants belong to var. floribunda (Miq.) $\mathrm{H}$. Huber, the Old World representative of the species, formerly recognized as $P$. leptostachya Hook. \& Arn. It is said to be distinguished from the typical variety especially by its non-stipitate fruits.

Peperomia lasiostigma C. DC.

Endemic to Fiji; probably found on most of the high islands. St John 18112. ROG 6759, peaks E above gardens in valley NW of Yalobi, local on rocky ledges in open forest. The Wayan plant belongs to the type variety, which is found on numerous other Fijian high islands.

\subsection{PIPERACEAE}

Piper puberulum Benth. aqonaaqona, aqoaqona Widespread in Fiji's forests. St John 18062. ROG 6371, Lekutu, occ. in shady forest, fruit ripe.

Formerly known as Macropiper puberulum. The Wayan plant belongs to what has been recognized as a glabrous form of the species (FVN 2: 68). Illn: FV t. 75.

\subsection{PITTOSPORACEAE}

Pittosporum brackenridgei A. Gray

Rather local in Fiji's drier forests. St John 18145, "tuba". ROG 6699, SE slopes of Vatunareba, $2 \mathrm{~m}$ tall, uncommon in lower-altitude forest. Illn: USEE 15, Atlas pl. 17 A.

\section{Pittosporum rhytidocarpum A. Gray}

Endemic to Fiji, widespread in forest. St John 18050, Naruarua Gulch, “mbau”. Illn: USEE 15, Atlas pl. 18.

\subsection{PORTULACACEAE}

\section{Portulaca samoensis Poelln.}

Rather local on Fiji's coast (Waya, the two largest islands and several others). St John 18152, Nakawa Gulch, "ndomindomi".

\subsection{RHAMNACEAE}

\section{Alphitonia franguloides A. Gray}

Endemic to Fiji, widespread and often abundant in forest. St John 18116, "ndoi ndra". ROG 6518, $4 \mathrm{~m}$ tall $25 \mathrm{~cm}$ dbh crooked-trunked tree in scrub, especially the branchlets smelling of oil-of-wintergreen. Illn: USEE 15, Atlas pl. 22 B.

Alphitonia zizyphoides (Spreng.) A. Gray doi Widespread and often abundant in Fiji's forests. St John 18019, Olo Creek, N of Yalobi, “ndoi ndu". Illn: USEE 15, Atlas pl. 22 A.
Colubrina asiatica (L.) Brongn. $k \bar{a}$ vere, vere Widespread on Fiji's coast. St John 18031, "sili". ROG 6357 , gardens in valley NW of Yalobi, $3 \mathrm{~m}$ tall bush edge treelet, ripe fruit. $R O G$ 6463, Yalobi, $2 \mathrm{~m}$ tall scandent plant at lagoon edge.

Rhamnella vitiensis (Benth.) A.C. Sm. wata Local in Fiji (mostly the high islands). ROG 6404, Waya Levu gardens, shrub in regrowth.

\section{Smythea lanceata (Tul.) Summerhayes}

Uncommon in Fiji (Waya and the two largest islands), in dry open scrub. $D A 13670$, Yalobi.

Illn: FV t. 14, as Smythea pacifica.

\section{Ventilago vitiensis A. Gray}

Quite widespread in Fiji. St John 18105, "wawa". $R O G$ 6322, gardens in valley NW of Yalobi, common in forest on bouldery slope. ROG 6694, SE slopes of Vatunareba, in dry forest.

\subsection{RHIZOPHORACEAE}

Bruguiera gymnorrhiza (L.) Lam. lailai Widespread in Fiji's mangrove. ROG 6277, Yalobi, 6 m tall, at lagoon edge.

Rhizophora stylosa Griffith tiritiri Widespread in Fiji's mangrove. ROG 6409, Yalobi, to c. $6 \mathrm{~m}$ tall, dominant at lagoon edge.

\subsection{RUBIACEAE}

\section{Antirhea inconspicua (Seem.) Christophersen}

Widespread in Fiji's dry coastal forests. ROG 6431, towards the peaks $\mathrm{N}$ of Yalobi, in forest among boulders. ROG 6721 , SE slopes of Vatunareba, occ. in dry open forest, ripe fruit.

\section{Badusa corymbifera (G. Forst.) A. Gray}

Widespread in Fiji's dry rocky forests, often on limestone (but not so on Waya). St John 18099, "tarutaru nikora[ni koro]". St John 18133. St John 18163, “tarutaru”. ROG 6708 , towards high point NE of Olo stream, $2 \mathrm{~m}$ tall shrub, local in forest, flrs scentless by day.

Dolicholobium oblongifolium A. Gray

Endemic to Fiji, widespread and abudant in light forest on the high islands. $R O G 6798$, E side of peaks above Waya Levu, $3 \mathrm{~m}$ tall bushy trees, local in forest towards ridge crest.

\section{Gardenia grievei Horne ex Baker}

Endemic to Fiji, known just from Waya and Vanua Levu. ROG 6478, slope W of Yalobi, $2.5 \mathrm{~m}$ tall $5 \mathrm{~cm}$ $\mathrm{dbh}$, uncommon in forest of rocky gully. $R O G 6680, \mathrm{SE}$ slopes of Vatunareba, $2.5 \mathrm{~m}$ tall, local in light dry forest.

Guettarda speciosa L. buatoka

Widespread on Fiji's coast. ROG 6284, Yalobi, by the school, $4 \mathrm{~m}$ tall, on sandy beach rear. $R O G 6828$, beach at Olo stream mouth, common at scrub edge, to c. $8 \mathrm{~m}$ tall. 


\section{Guettarda wayaensis R.O. Gardner}

Endemic to Fiji. ROG 6498, slope $\mathrm{W}$ of Yalobi, $6 \mathrm{~m}$ tall $10 \mathrm{~cm} \mathrm{dbh}$, occ. in forest of rocky gully. ROG 6700, SE slopes of Vatunareba, local in low-altitude forest, to 12 $\mathrm{m}$ tall $20 \mathrm{~cm} \mathrm{dbh}$, old fruit on ground. Not relocated in 2017. Described from Waya, and subsequently reported from westernmost Vanua Levu (Keppel \& Tuiwawa 2007: 463). Resembles a hybrid between Antirhea inconspicua and Guettarda speciosa.

\section{Hedyotis lapeyrousii DC.}

Widespread in Fiji's disturbed forests. ROG 6344, Nagwa, on clay bank above stream in secondary forest, rare, apparently without a Wayan name. Sometimes considered conspecific with the Asian taxon H. auricularia.

\section{Ixora vitiensis A. Gray}

Endemic to Fiji, known from five islands. St John 18047, "rauyangili". St John 18118. St John 18140, "rautolu". $R O G$ 6330, valley NW of Yalobi, 2 m tall treelets, occ. in forest among boulders. $R O G 11318, \mathrm{~W}$ above grassy mid-part of Olo stream, common on rock outcrops.

\section{Mastixiodendron flavidum (Seem.) A.C. Sm.} Endemic to Fiji (Waya, the two largest islands, and Rabi). ROG 6501, slope $\mathrm{W}$ of Yalobi village, towards Vatunareba, local in open forest, ripe fruit. ROG 6507, loc. cit., $3 \mathrm{~m}$ tall, uncommon in forest of rocky gully.

\section{Morinda citrifolia $\mathrm{L}$.}

kura

Widespread in Fiji's coastal forests.

$R O G$ 6442, Naseva beach, $3 \mathrm{~m}$ tall trees in scrub, fruit nearly ripe (yellow but firm).

\section{Morinda myrtifolia A. Gray}

wata

Widespread in Fiji's drier forests and scrub. ROG 6483, W above Nagwa, on rocky slope, fruit hard, purple.

\section{Mussaenda raiateensis J.W. Moore}

bobo

Widespread in Fiji, in open forest and regrowth. $D A$ 13674, below Yalobi and Natawa. ROG 6379, Yalobi, brought from bush and cultivated at one house.

\section{Ophiorrhiza laxa A. Gray}

Endemic to Fiji, common and widespread in mesic forests. St John 18126 [type of O. leptantha var. yasawana Fosberg], "karaua". ROG 6786, towards summit of Vatunareba, $40 \mathrm{~cm}$ tall, uncommon in gully forest. $R O G$ 6852, E side of peaks above Wayalevu, $50 \mathrm{~cm}$ tall, locally common along rocky channel of gully on steep forested slope. See Darwin (1976) for photographs of this species.

\section{Ophiorrhiza peploides A. Gray}

Endemic to Fiji, common in rocky mesic forests. $R O G$ 6783 , towards Vatunareba summit, occ. in uppermost gully forest. ROG 6788, E side of peaks above Waya Levu, $40 \mathrm{~cm}$ tall, locally common in mesic gully forest. See Darwin (1976) for photographs of this species.
Psychotria amoena A.C. Sm.

Endemic to Fiji (Waya and the two largest islands). $R O G$ 6348, Nagwa, treelets to c. $3 \mathrm{~m}$ tall, locally common in older forest. $R O G 6470$, Lekutu, locally common in shady forest; new growth from cut stump in Piper methystichum garden. ROG 6714, high point NE of Olo stream, $2 \mathrm{~m}$ tall, common in forest, ripe fruit. $R O G$ 6816, towards summit of Vatunareba, common in mid- and higher-altitude gully forest, ripe fruit.

\section{Psychotria tephrosantha A. Gray}

Endemic to Fiji, widespread and abundant in the drier forests. ROG 6743, E side of peaks above Waya Levu, juveniles creeping on rocks and bases of tree trunks. ROG 6792, loc. cit., common here, scrambling on lower parts of trees in forest towards ridge crest, ripe fruit.

\section{Psychotria volii R.O. Gardner}

Endemic to Fiji, known only from Waya. ROG 6488, peaks $\mathrm{W}$ above Nagwa, $3 \mathrm{~m}$ tall, along ridge crest. $R O G$ 6500 , slope W of Yalobi, towards Vatunareba, local in open forest. $R O G$ 6727, SE peak of Vatunareba, treelet of light dryish forest. $R O G$ 6754, 6805, 6809, 6860, peaks E above gardens in valley NW of Yalobi, relict tree on dry fire-swept ridge. $R O G 6858$, towards $\mathrm{S}$ peak of Vatunareba, $2 \mathrm{~m}$ tall, in light dry forest. At the time of its description this tree was not seen in abundance anywhere on Waya. Continued firing of the island's hillsides and the presence of goats now seriously threaten its survival.

Psydrax odorata (G. Forst.) A.C. Sm. \& S.P. Darwin Widespread in Fiji, in dry open forest. St John 18101, "bolabatu". ROG 6432, peaks N of Yalobi, 300 m; 3 m tall, in forest among boulders. ROG 6676, SE slopes of Vatunareba, locally common in dry light forest, fruit ripe.

Tarenna sambucina (G. Forst.) Durand ex Drake Widespread in Fiji, in dry forest, mostly near the coast. No specimen known from Waya; sighted by $R O G$ in 1991 on the peak opposite Nagwa.

\subsection{RUTACEAE}

Euodia hortensis J.R. \& G. Forst. $u c i$ Widespread in Fiji, usually just as a village plant. No specimen known from Waya; sighted by $R O G$ at Yalobi village in the 1990s.

\section{Melicope cucullata}

(Gillespie) A.C. Sm. qālaka, rautolu Apparently rather infrequent in Fiji. St John 18034, "rautolu". ROG 6328, gardens in valley NW of Yalobi, $3 \mathrm{~m}$ tall, occ. in relic forest on bouldery slope. $R O G$ 6842 , high point NE of Olo stream, $3 \mathrm{~m}$ tall, common in open forest. $R O G$ 6406, regrowth in Waya Levu gardens, $3 \mathrm{~m}$ tall.

The Wayan plant belongs to var. cucullata, known from Waya and the three largest islands. 


\section{Micromelum minutum}

(G. Forst.) Seem.

madamada

Widespread in Fiji's drier secondary forests. St John 18017, "mandamanda". ROG 6394, Olo stream, 3 m tall treelet at scrub edge.

\subsection{SANTALACEAE}

\section{Santalum yasi Seem.}

In Fiji known from several of the high islands, but not Taveuni. No specimen is known from Waya, but the plant is said to have been cultivated on the island, at least in former times. Said to grow in other parts of Fiji from near sea-level to c. $200 \mathrm{~m}$, in dry or open forest, often in the talasinga, that is, areas of infertile, fire-swept open ground (FVN 3:738). Apparently overlooked by Keppel \& Tuiwawa (2007) in their list of dry-zone forest species. Illn: FV t. 55.

\subsection{SAPINDACEAE}

Arytera brackenridgei (A. Gray) Radlk. marasa Widespread in Fiji's forests. St John 18115, "marasa". ROG 6410, slope above Naseva Beach, 6 m tall 20 $\mathrm{cm} \mathrm{dbh}$, in young forest. $R O G$ 6683, SE slopes of Vatunareba, $3 \mathrm{~m}$ tall, dominant in dry ridge scrub at middle and higher altitudes.

\section{Cupaniopsis leptobotrys (A. Gr.) Radlk.}

Endemic to Fiji (Waya and four other high islands), often abundant in forest. $R O G$ 6795, E side of peaks above Waya Levu, $3 \mathrm{~m}$ tall $3 \mathrm{~cm}$ dbh, locally common at one place on ridge crest.

\section{Dodonaea viscosa (L.) Jacq.} osi Widespread in Fiji on dry grassy hillsides and scrub and open rocky forest. St John 18005.

Dominant of lower E slope of Vatunareba (after many fires ?), to c. $1.5 \mathrm{~m}$ tall $(R O G, 2017)$.

\section{Elattostachys apetala Radlk.} marasa

Widespread in Fiji's forests. St John 18169, "marasa". ROG 6484, W above Nagwa, $12 \mathrm{~m}$ tall $25 \mathrm{~cm}$ dbh tree in forest among boulders. ROG 6728, SE slope of Vatunareba, $10 \mathrm{~m}$ tall smooth-barked tree at edge of gully forest. Formerly known as E. falcata.

Guioa rhoifolia (A. Gray) Radlk.

marasa

Quite widespread in Fiji's forests. St John 18143. ROG 6537 , high point on E side of Olo stream, $5 \mathrm{~m}$ tall, in open forest. ROG 6845, E side of peaks above Waya Levu, $5 \mathrm{~m}$ tall, in open forest towards ridge crest. In a revision of the genus (van Welzen 1989; see also FVN 5: 593) the St John specimen cited above was said to belong to a new species G. punctata van Welzen, endemic to Fiji. But my two collections agree better with $G$. rhoifolia, having relatively small, straight leaflets (blades $7 \mathrm{~cm}$ long or less), with only a single domatium or often, none. The critical petal-scales seem to be very short and carry robust clavate crests, which does not agree with van Welzen's description of G. punctata. Perhaps both species are present on Waya. Neither G. punctata nor G. rhoifolia is noted by Keppel \& Tuiwawa (2007) as characteristic of Fijian dry-zone forests.

Pometia pinnata J.R. \& G. Forst. tawa

Widespread in Fiji, at least as a cultivated plant. No specimen is known from Waya; seen by ROG at Yalobi village in 1990s. Illn: FV t. 10.

\section{Sapindus vitiensis A. Gray} tōsiga

Widespread but local in Fiji's coastal forests (the three largest islands and several others). ROG 6519, mouth of stream at W end of Yalobi, $10 \mathrm{~m}$ tall $30 \mathrm{~cm}$ dbh crooked-trunked tree among rocks, ripe fruit on ground, yellow-brown, with a pleasant odour. $R O G$ 6782, towards head of Yalobi's village gardens, $10 \mathrm{~m}$ tall $30 \mathrm{~cm}$ dbh, occ. in mesic gully-forest. Sometimes regarded as conspecific with $S$. saponaria L., an almost pantropical taxon.

\subsection{SAPOTACEAE}

Burckella richii (A. Gray) Lam bau

Uncommon in Fiji (Waya and one of the Lau Is.). ROG 6324, gardens in valley NW of Yalobi, trees to $15 \mathrm{~m}$ tall $40 \mathrm{~cm}$ dbh, occ. in relict forest, bark grey, regularly rectangular-platy. $R O G$ 6663, E above Olo stream, 12 $\mathrm{m}$ tall $40 \mathrm{~cm} \mathrm{dbh}$, on grassy hillside, sap yellowishcream and hardly sticky. $R O G$ 6867, SE slope of Vatunareba, $10 \mathrm{~m}$ tall $40 \mathrm{~cm}$, locally common in gully forest; bat-gnawed fruit on ground, green, $7.5 \times 5 \mathrm{~cm}$, a thin fleshy layer over spongy tissue. Fig. 7.

\section{Manilkara vitiensis}

(H.J. Lam \& Olden) B. Meeuse bau, bau som Endemic to Fiji, local in rocky coastal forest (Waya, Mamanucas, northern Lau Group). ROG 6689, SE slopes of Vatunareba, $10 \mathrm{~m}$ tall, in gully forest. $R O G$ 6732, loc.cit., windswept $6 \mathrm{~m}$ tall $15 \mathrm{~cm}$ dbh tree on edge of gully forest.

\section{Palaquium fidjiense Pierre ex Dubard} bau

Endemic to Fiji, rather local (Waya, the two largest high islands, and several others).

ROG 6711, high point NE of Olo stream, $10 \mathrm{~m}$ tall, local in forest below summit. ROG 6791, E side of peaks above Waya Levu, $3 \mathrm{~m}$ tall, local near ridge crest, flrs borne just below leaves.

Planchonella garberi Christopherson bau, bau leke Scattered in low- to mid-altitude forest (Waya, Viti Levu, and elsewhere). St John 18168, "tandiri”. $R O G$ 6479, slope W of Yalobi, $5 \mathrm{~m}$ tall $10 \mathrm{~cm}$ dbh tree in forest of rocky gully. $R O G 6725$, SE slopes of Vatunareba, $10 \mathrm{~m}$ tall $15 \mathrm{~cm}$ dbh smooth-barked tree, fruit green but apple-scented, nearly ripe ? 


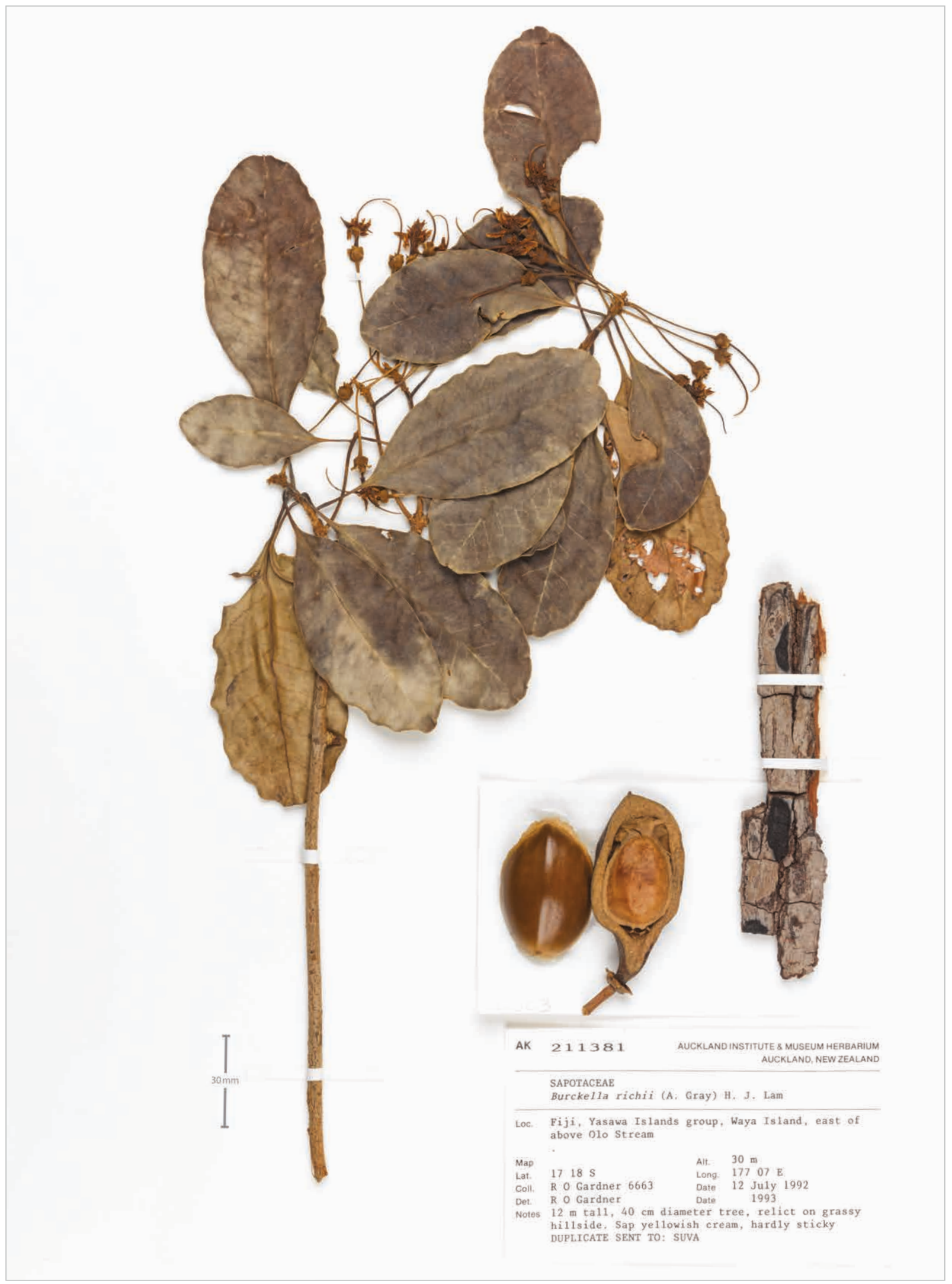

Figure 7. Burckella richii, AK211381. (c) Auckland Museum CC BY. 
Planchonella smithii (van Royen) A.C. Sm. bau Endemic to Fiji (Waya and three largest islands). ROG 6836, high point NE of Olo stream, a single $10 \mathrm{~m}$ tall 25 $\mathrm{cm}$ dbh tree in forest on mesic site (old talus slope), the fruit unripe (?), green under a brown scurf, to $5 \mathrm{~cm} \varnothing$.

\section{Planchonella tahitensis}

(Nadeaud) Pierre ex Dubard bau, bau levu Widespread in Fiji's coastal forests (absent from Viti Levu). $R O G$ 6533, between Yalobi village and Naseva beach, $5 \mathrm{~m}$ tall $15 \mathrm{~cm}$ dbh tree in scrub. ROG 6399, $10 \mathrm{~m}$ tall $30 \mathrm{~cm}$ dbh, bark rough and rectangularly fissured, fruit flattened-globose, glaucous, $3.5 \mathrm{~cm} \varnothing$, nearly ripe. $R O G$ 6450 , Yalobi, at the coast $\mathrm{E}$ past school, $4 \mathrm{~m}$ tall, in coastal forest remnant, flrs not scented. ROG 6726, SE slopes of Vatunareba, $10 \mathrm{~m}$ tall $15 \mathrm{~cm}$ dbh, occ. in dry forest. Formerly known as P. grayana (Swenson et al. 2013).

\subsection{SOLANACEAE}

Solanum americanum Mill. $\quad$ boro dū, boroboro Widespread in Fiji as a village and cultivation weed. No specimen is known from Waya but the species is known from elsewhere in the Yasawa Is.: Weiner 248, Yaqeta I.

\section{Solanum vitiense Seem.}

Quite widespread in Fiji's forests. ROG 6524, Lekutu, $3 \mathrm{~m}$ tall treelets at trackside; seen at only two other places. Illn: FV t. 36.

\subsection{STERCULIACEAE (APG IV: Malvaceae)}

\section{Heritiera littoralis Ait.}

kea ivi na kula

Widespread in Fiji, often abundant at the inland edge of mangrove. St John 18095, "kaenaivinakaka". ROG 6531, Olo stream, sprouts from a cut stump at lagoon edge.

\section{Kleinhovia hospita L.}

Common in Fiji's forests. ROG 6315, E of Olo stream, a few $4 \mathrm{~m}$ tall trees together at edge of forest among boulders; 6718 , loc. cit., several trees to $8 \mathrm{~m}$ tall, not seen elsewhere, said to be "a kind of vau".

Melochia degeneriana A.C. Sm.

vuvudi Endemic to Fiji, quite common on Viti Levu and nearby islands. St John 18009, “pupuinti”. ROG 6268, Yalobi, to c. $4 \mathrm{~m}$ tall. ROG 6361, Yalobi, ridge above Sayaba compound, $3 \mathrm{~m}$ tall $20 \mathrm{~cm}$ dbh treelets, occ. on grassy slope, fruit ripe.

\subsection{THYMELAEACEAE}

Phaleria disperma (G. Forst.) Baill.

tarutaru Widespread in Fiji's coastal forests. ROG 6445, 6780, Naseva Beach, 2-3 m tall shrubs, uncommon on sandy beach frontage.

Phaleria ixoroides Fosb.

tarutaru Endemic to Fiji; known only from drier forests of Waya and Viti Levu. St John 18123 [type of species], small tree $5 \mathrm{~m}$ high, in woods by stream, "tarutaru". ROG 6388, Yalobi to Nalauwaki, stream S of Koroimatalevu peak (high point $\mathrm{S}$ of Lekutu), $1.5 \mathrm{~m}$ tall, seen twice at track edge. ROG 6669, above Olo stream, locally common in streamside forest. ROG 6695, SE slopes of Vatunareba, $2 \mathrm{~m}$ tall bush in dry forest.

\section{Phaleria lanceolata (A. Gray) Gilg}

Endemic to Fiji; known only from Waya and Vanua Levu. ROG 6723, SE slope of Vatunareba, a few $2 \mathrm{~m}$ tall bushes in dry open forest, ripe fruit red, oblong, 1.6 $x 1.2 \mathrm{~cm}$. Presumably recognized by the Wayans as a kind of tarutaru. The identification is a tentative one; the relatively small size (c. $8 \mathrm{~cm}$ long and $2.5 \mathrm{~cm}$ wide) of the leaves of $R O G 6723$ and the lack of persistent involucral bracts, would, according to Smith (FVN 2: 581), rule out $P$. glabra (Turrill) Domke but not $P$. acuminata (A. Gray) Gilg.

Wikstroemia coriacea Seem.

mudu

Widespread in Fiji's drier forests. St John 18006. ROG 6323 , gardens in valley NW of Yalobi, $2 \mathrm{~m}$ tall treelet in light forest, ripe fruit. The name $W$. foetida (L.f.) A. Gray has been commonly used for this species.

\subsection{TILIACEAE (APG IV: Malvaceae)}

\section{Grewia crenata}

(J.R. \& G. Forst.) Schinz \& Guillaumin nice Widespread in Fiji's open, rather dry coastal forests. St John 18150. ROG 6374, Lekutu, $2 \mathrm{~m}$ tall, occ. in shady places.

\section{Trichospermum richii (A. Gray) Seem.}

Widespread in forest of Fiji's larger islands. ROG 6706, towards high point $\mathrm{N}$ of Olo stream, $3 \mathrm{~m}$ tall, local on forest margin. The usual Fijian name mako for this distinctive tree is probably used on Waya. Illn: USEE 15, Atlas pl. 14, as Diclidocarpus richii.

* Triumfetta rhomboidea Jacq. qatima

Widespread and often abundant in Fiji, often on open scrubby hillsides, etc. ROG 6256, Yalobi, $1 \mathrm{~m}$ tall, common weed here and throughout island, ripe fruit.

\subsection{ULMACEAE (APG IV: Cannabaceae)}

Parasponia andersonii (Planch.) Planch. drou Widespread in Fiji, a forest pioneer. DA 13673, below Yalobi and Natawa. ROG 6299, Yalobi village, $3 \mathrm{~m}$ tall, among grass on dry slope.

\section{Trema cannabina Lour.}

Widespread in Fiji, a forest pioneer. ROG 6705, towards high point NE of Olo stream; $3 \mathrm{~m}$ tall, local on forest edge, ripe fruit, "rome alewa". $R O G$ 11296,above Vunasinu Point (between village and Olo stream mouth), uncommon in dry scrub. This species is much less common on Waya than the very similarlooking Parasponia andersonii. There appears to be no well-attested, contrastive Wayan name for it. 


\subsection{URTICACEAE}

Boehmeria virgata (G. Forst.) Guillemin rōmē Local in Fiji's drier forests (Waya, the three larger islands, and others). ROG 6797, E side of peaks above Waya Levu, at one place in open mesic forest on talus.

\section{Cypholophus heterophyllus (Wedd.) Wedd.}

Widespread in Fiji's forests. St John 18076. ROG 6383, 6386 , stream S of Koroimatalevu peak (high point S of Lekutu), to $1.5 \mathrm{~m}$ tall, local in scrub about the gardens of Nalauwaki village.

Illn: FV t. 62, as Boehmeria harveyi.

Dendrocnide harveyi (Seem.) Chew salato

Widespread in Fiji's forests (Waya, the three larger islands, and others). $R O G$ 6416, slope above Naseva beach, $10 \mathrm{~m}$ tall $80 \mathrm{~cm}$ basal $\varnothing$ trees at foot of cliff below peaks. ROG 6512, slope on NW side of Vatunareba peak, to $12 \mathrm{~m}$ tall, common on good soil of old talus slope.

Illn: FV t. 59, as Laportea harveyi.

Leucosyke corymbulosa (Wedd.) Wedd. rōme Widespread in Fiji's forests and scrub, mostly near the coast. St John 18065, "kalakuro". ROG 6255, Yalobi, $3 \mathrm{~m}$ tall shrub in dryish scrub, ripe fruit mucilaginous, slightly sweet and bitter.

\section{Pipturus argenteus}

\section{(G. Forst.) Wedd.}

rōmē, rōmē kavukavu

In Fiji known mainly from drier forests of Viti Levu. St John 18077. ROG 6428, gardens in valley NW of Yalobi, $2.5 \mathrm{~m}$ tall treelet in grassy scrub. ROG 6662, E above Olo stream, $2 \mathrm{~m}$ tall bush on rock face. $R O G$ 6752, E side peak above Waya Levu, occ. in open forest, ripe fruit.

Procris pedunculata (J.R. \& G. Forst.) Wedd. Widespread in Fiji in rocky forests. No specimen is known from Waya. Sighted by ROG 22 July 1992, east from central peaks towards Lekutu, a colony in rock crevice in light shade.

\subsection{VERBENACEAE (APG IV: Lamiaceae)}

Clerodendrum inerme (L.) Gaertn. aria, ria Widespread and abundant on Fiji's coasts. ROG 6397, Waya Levu village, sprawling $2 \mathrm{~m}$ tall shrub on coral gravel berm at beach rear.

Premna protrusa A.C. Sm. \& S. Darwin araro Endemic to Fiji, widespread in coastal and inland places. $D A$ 13671, below Yalobi and Natawa. $R O G$ 6690 , SE slopes of Vatunareba, $8 \mathrm{~m}$ tall $25 \mathrm{~cm} \mathrm{dbh}$, occ. in dry forest, ripe fruit.

Illn: FV t. 43, as P. taitensis [except for a detached branchlet at lower left, which belongs to P. serratifolia; FVN 5: 192].
Premna serratifolia $\mathrm{L}$.

araro Widespread in Fiji's coastal forests. St John 18136. DA 13669, Yalobi. ROG 6298, Yalobi, $4 \mathrm{~m}$ tall $10 \mathrm{~cm} \mathrm{dbh}$ bushes on dry grassy hillside. See under P. protrusa for reference to FV t. 43.

Vitex trifolia $\mathrm{L}$. drala

Common in Fiji, usually at or near the coast. $R O G$ 6301, Yalobi, ridge above Sayaba compound, prostrate bushes, common among rocks on dry grassy slope, not eaten by goats. ROG 6354, coast E of Olo end of Yalobi, $3 \mathrm{~m}$ tall treelet behind beach. Some of the Wayan plants (e.g., ROG 6301) belong to var. subtrisecta, whose leaves usually have three leaflets; the type variety (e.g., $R O G$ 6354) has three to five.

\subsection{VIOLACEAE}

\section{Agatea violaris A. Gray}

Widespread in Fiji's forests. ROG 6822, SE side of range above track between Yalobi and Waya Levu, scandent in light forest on ridge. Illn: USEE 15, Atlas pl. 7.

\section{Rinorea benghalensis (Wall.) Kuntze}

In Fiji known only from Waya (Gardner 1997). ROG 6494, slope W of Yalobi, towards Vatunareba, $2.5 \mathrm{~m}$ tall, local in open forest. ROG 6701, E slopes of Vatunareba, $3 \mathrm{~m}$ tall, locally common in mid- and higher-altitude gully forest, not seen on other peaks of Waya. An earlier record of $R$. benghalensis for Fiji (Ovalau) is wrong, being based on a specimen of Casearia richii (FVN 2: 644).

\subsection{VITACEAE}

Tetrastigma vitiense (A. Gray) A.C. Sm.

Endemic to Fiji (Waya and several of the higher islands). $R O G$ 6799, 6846, E side of peaks above Waya Levu, occ. in open ridge thickets.

\section{ACKNOWLEDGEMENTS}

I am grateful for the help I have had from the Botany Department (AK) of the Auckland War Memorial Museum, whose Curator, Ewen Cameron, and Collections Manager, Dhahara Ranatunga, encouraged this project and attended to all biosecurity and curatorial matters.

Barbara Parris, Bill Sykes, Jan-Frits Veldkamp, Dick Watling and Art Whistler advised on taxonomic and ecological problems. Roger Munn was a good companion on my 2017 trip.

I first went to Waya with Andrew Pawley of the Australian National University, who has been studying all aspects of "the words of Waya" since the 1960s; consequently, I was readily given permission by the Tui Waya of the time, Ratu Nalotonidave Naivalu, to collect throughout his island. I am also indebted to those Wayans who have shared their plant-knowledge with me, in particular, my two friends at Yalobi, Ms. Adi Kelera Sayaba and Mr. Seremaia Tuicuvu. 


\section{REFERENCES}

Adema, F., 1993. Elattostachys (Blume) Radlk. in Fiji. Pacific Science 47: 295-297.

Angiosperm Phylogeny Group, 2016. An update of the Angiosperm Phylogeny Group classification for the orders and families of flowering plants: APG IV. Botanical Journal of the Linnaean Society 181: 1-20. doi.org/10.1111/boj.12385

Brackenridge, W.D., 1855. United States Exploring Expedition 1838-1842. Vol. 16 Cryptogamia: Filices. Atlas. C. Sherman, Philadelphia.

Brownlie, G., 1977. The Pteridophyte Flora of Fiji. Vaduz: J. Cramer.

Brownsey, P.J. and L.R. Perrie, 2011. A revised check-list of Fijian ferns and lycophytes. Telopea 13: 513-562.

Chen C.W., L. Perrie, D. Glenny, and W.L. Chiou, 2017. Sol Amazing: Lycophytes and Ferns of the Solomon Islands. Taichung: National Museum of Natural Science.

Clayton, W.D. and N. Snow, 2010. A Key to Pacific Grasses. Kew: Royal Botanic Gardens.

Darwin, S.P., 1976. The Pacific species of Ophiorrhiza L. (Rubiaceae). Lyonia 1: 47-102.

Derrick, R.A., 1965. The Fiji Islands. 2nd revd edn. Suva: Government Printer.

Forster, P.I., 1992. A taxonomic revision of Sarcolobus (Asclepidaceae: Marsdenieae) in Fiji. Australian Systematic Botany 5: 593-596.

Forster, P.I., 1994. Revision of Euphorbia plumerioides Teijsm. ex Hassk. (Euphorbiaceae) and allies. Austrobaileya 4: 245-264. doi.org/10.1071.5139920593

Gardner, R.O., 1997. New and noteworthy plants from Fiji. New Zealand Journal of Botany 35: 487-492. doi.org/10.1080/0028825X.1987.10410172

Gardner, R. and A. Pawley, 2006. Annotated list of local plant names from Waya Island, Fiji. Records of the Auckland Museum 43: 97-108.

Geraghty, P., 1983. The History of the Fijian Languages. University of Hawaii Press.

Gillespie, T.W. and T. Jaffré, 2003. Tropical dry forest in New Caledonia. Biodiversity and Conservation 12: 1687-1697.

Gray, A., 1854. United States Exploring Expedition 1838-1842. vol. 15. Phanerogamia. Vol. 1. Philadelphia: C. Sherman.

Gray, A., 1856. United States Exploring Expedition 1838-1842. vol. 15. Phanerogamia, Atlas. Philadelphia, C. Sherman.

Henderson, C.P \& I.R. Hancock, 1988. A Guide to the Useful Plants of the Solomon Islands. Honiara: Ministry of Agriculture \& Lands.
Holttum, R.E., 1964. The tree-ferns of the genus Cyathea in Australasia and the Pacific. Blumea 12: 241-274.

Hopkins, H.F. and I.J. Menzies, 1995. The Flora of Motupore Island. Port Moresby, UPNG.

Hovenkamp P.H. and F. Miyamoto, 2005. A conspectus of the native and naturalized species of Nephrolepis (Nephrolepidaceae) in the world. Blumea 50: 279-322.

Hunt, T., K. Aronsen, E. Cochrane, J. Field, L. Humphrey and T. Reith, 1999. A preliminary report on archaeological research in the Yasawa Islands, Fiji. Domodomo 12: 5-43.

Keppel, G. and M.W. Tuiwawa, 2007. Dry zone forests of Fiji: species composition, life history traits, and conservation. New Zealand Journal of Botany 45: 545-563. doi.org/10.1080/0028825079509738

Laubenfels, D. J. de and F. Adema, 1998. A taxonomic revision of the genera Cycas and Epicycas gen. nov. (Cycadaceae). Blumea 43: 351-400.

Morrison, C., G. Keppel, N. Thomas, I. Rounds, and P.S. Harlow, 2009. Critically Endangered Fijian Crested Iguana (Brachylophus vitiensis) shows habitat preference for globally threatened tropical dry forest. Pacific Science 63: 223-242. doi.org/10.2984.049.063.0205

Middleton, D.J., 2002. Revision of Alyxia (Apocynaceae). Part 2: Pacific Islands and Australia. Blumea 47: 1-93.

Mueller-Dombois, D. and F.R. Fosberg, 1998. Vegetation of the Tropical Pacific Islands. Springer.

Nakamura, T. and S. Matsumoto (eds), 2008. Illustrated Flora of Ferns and Fern Allies of South Pacific Islands. Tokyo, Tokai University Press.

Orchard, A.E. and P.M. McCarthy (eds), 1998. Flora of Australia. Vol. 48. ABRS/CSIRO.

Peekel, G., 1984. Flora of the Bismarck Archipelago for Naturalists. Lae, Office of Forests.

Seemann, B., 1865-1873. Flora Vitiensis. London, L. Reeve \& Co.

Smith, A.C., 1979-1991. Flora Vitiensis Nova. Vols 1-5 [1979, 1981, 1985, 1988, 1991; also Comprehensive Indices, 1996. Hawaii, Pacific Tropical Botanical Gardens.

Swenson, U., S. Nylinder, and J. Munzinger, 2013. Towards a natural classification of Sapotaceae in Oceania and Southeast Asia. Taxon 62: 746-770. doi.org/10.12705/624.11

Twyford, I.T. and A.C.S. Wright, 1967. The Soil Resources of the Fiji Islands. Suva: Government of Fiji.

Welzen, P. van, 1989. Guioa Cav.; taxonomy, phylogeny and historical biogeography. Leiden Botanical Series 12: $1-314$. 
APPENDIX 1: Summary list.

$\mathbf{e}=$ species endemic to Fiji

* = may not be indigenous to Fiji

\section{Ferns and lycophytes}

\section{ASPLENIACEAE}

Asplenium amboinense Willd.

Asplenium polyodon $\mathrm{G}$. Forst.

BLECHNACEAE

Blechnum orientale $\mathrm{L}$.

CYATHEACEAE

Cyathea lunulata (G. Forst.) Copel.

DAVALLIACEAE

Davallia heterophylla Sm.

Davallia solida (G. Forst.) Sw.

DENNSTAEDTIACEAE

Microlepia speluncae (L.) T. Moore

Pteridium esculentum (G. Forst.) Cockayne

DICKSONIACEAE

Calochlaena straminea (Labill.) M.D. Turner \& R.A. White DRYOPTERIDACEAE

e Polystichum pilosum Copel.

GLEICHENIACEAE

Dicranopteris linearis (Burm.f.) Underw.

HYMENOPHYLLACEAE

Trichomanes atrovirens (C. Presl) Kunze

LOMARIOPSIDACEAE

Nephrolepis hirsutula (G. Forst.) C. Presl

LYCOPODIACEAE

Lycopodiella cernua (L.) Pic.Serm.

LYGODIACEAE

Lygodium reticulatum Schkuhr

MARATTIACEAE

Angiopteris evecta (G. Forst.) Hoffm.

POLYPODIACEAE

Drynaria rigidula (Sw.) Bedd.

Microsorum grossum (Langsd. \& Fisch.) S.B. Andrews

e Prosaptia vomaensis (Brownlie) Parris

Pyrrosia lanceolata (L.) Farw.

PSILOTACEAE

Psilotum nudum (L.) P. Beauv.

PTERIDACEAE

Acrostichum aureum $\mathrm{L}$.

Adiantum hispidulum Sw.

* Adiantum trapeziforme L.

Antrophyum plantagineum (Cav.) Kaulf.

Cheilanthes nudiuscula (R.Br.) T. Moore

Doryopteris concolor (Langsd. \& Fisch.) Kuhn

Haplopteris elongata (Sw.) E.H. Crane

Pteris tripartita $\mathrm{Sw}$.

* Pteris vittata $\mathrm{L}$.

Taenitis pinnata (J. Sm.) Holttum

SELAGINELLACEAE

Selaginella laxa Spring

Selaginella firmula A. Braun ex Kuhn

Selaginella victoriae T. Moore

SCHIZAEACEAE

Schizaea dichotoma (L.) Sm.

TECTARIACEAE

Tectaria latifolia (G. Forst.) Copel.

THELYPTERIDACEAE

Macrothelypteris torresiana (Gaudich.) Ching

Sphaerostephanos invisus (G. Forst.) Holttum

\section{Gymnosperm}

\author{
CYCADACEAE \\ Cycas celebica Miq.
}

\section{Monocotyledons}

AGAVACEAE

* Cordyline fruticosa (L.) A. Chev

ARACEAE

* Alocasia macrorrhizos (L.) G. Don

* Amorphophallus paeoniifolius (Dennst.) Nicolson

* Cyrtosperma merkusii (Hassk.) Schott

Epipremnum pinnatum (L.) Engl.

ARECACEAE

Cocos nucifera $\mathrm{L}$.

* Pritchardia pacifica Seem. \& H. Wendl. CYMODOCEACEAE

Halodule pinifolia (Miki) den Hartog

Syringodium isoetifolium (Aschers.) Dandy

CYPERACEAE

Carex brunnea Thunb.

Carex dietrichiae Boeck.

Cyperus javanicus Houtt.

Fimbristylis cymosa $\mathrm{R}$. Br.

Fimbristylis dichotoma (Burm. f.) Kern

Fimbristylis ovata (Burm. f.) Kern

Gahnia aspera (R. Br.) Spreng.

Rhynchospora corymbosa (L.) Britton

Scleria lithosperma (L.) Sw.

Scleria polycarpa Boeck.

DIOSCOREACEAE

* Dioscorea bulbifera L.

* Dioscorea pentaphylla L.

HEMEROCALLIDACEAE

Geitonoplesium cymosum (R. Br.) A. Cunn. ex Hook. HYDROCHARITACEAE

Halophila minor (Zoll.) den Hartog

ORCHIDACEAE

Calanthe triplicata (Willemet) Ames

Dendrobium tokai Reichenb. f. ex Seem.

Eulophia pulchra (Thouars) Lindl.

Liparis condylobulbon Rchb. f.

Oberonia equitans (G. Forst.) Mutel

e Pseuderia smithiana C. Schweinf. Spathoglottis pacifica Rchb. f.

Taeniophyllum fasciola (G. Forst.) Seem. PANDANACEAE

Freycinetia urvilleana Hombron \& Jacq.

Pandanus tectorius Sol. ex Parkinson

POACEAE

* Cenchrus polystachios (L.) Morrone

Centotheca lappacea (L.) Desv.

Chrysopogon aciculatus (Retz.) Trin.

* Coix lacryma-jobi L.

* Cymbopogon coloratus (Hook. f.) Stapf

Cymbopogon refractus $\mathrm{R}$. Br.

Cyrtococcum oxyphyllum (Hochst. ex Steudel) Stapf

Digitaria setigera Roth ex Roem. \& Schultes

Heteropogon contortus (L.) P. Beauv. ex Roem. \& Schultes

Imperata conferta (J. Presl) Ohwi

Lepturus repens (G. Forst.) R. Br. 
Miscanthus floridulus (Labill.) Warb. ex K. Schum. \& Lauterb.

Oplismenus compositus (L.) Beauv.

Paspalum scrobiculatum L.

* Schizostachyum glaucifolium (Rupr.) Munro Stenotaphrum micranthum (Desv.) Hubbard Thuarea involuta (Forst. f.) R. Br. ex Sm. SMILACACEAE

Smilax vitiensis (Seem.) A. DC. in DC. TACCACEAE

* Tacca leontopetaloides (L.) Kuntze XANTHORRHOEACEAE

Dianella adenanthera (Forst. f.) R.F. Henderson ZINGIBERACEAE

* Curcuma longa $\mathrm{L}$.

* Zingiber zerumbet (L.) Sm.

\section{Dicotyledons}

\section{ACANTHACEAE}

Graptophyllum insularum (A. Gray) A.C. Sm. AIZOACEAE

Sesuvium portulacastrum (L.) L.

AMARANTHACEAE

* Achyranthes aspera L.

AMARANTHACEAE

Deeringia amaranthoides (Lam.) Merr.

ANACARDIACEAE

Dracontomelon vitiense Engl.

Pleiogynium timoriense (DC.) Leenh.

Rhus taitensis Guillemin

Semecarpus vitiensis (A. Gray) Engler

APIACEAE

Centella asiatica (L.) Urb.

APOCYNACEAE

Alyxia bracteolosa A. Gray

Alyxia stellata (J.R. \& G. Forst.) Roem. \& Schult.

Cerbera manghas $\mathrm{L}$.

Melodinus glaber Turrill

Ochrosia oppositifolia (Lam.) K. Schum.

Ochrosia vitiensis (Markgraf) Pichon

Tabernaemontana pandacaqui Lam.

ARALIACEAE

Polyscias multijuga (A. Gray) Harms

ASCLEPIADACEAE

Hoya autralis $\mathrm{R}$. $\mathrm{Br}$.

e Sarcolobus stenophyllus (A. Gray) P.I. Forst. ASTERACEAE

Wollastonia biflora (L.) DC.

BALANOPHORACEAE

Balanophora fungosa J.R. \& G. Forst.

BARRINGTONIACEAE

Barringtonia asiatica (L.) Kurz

Barringtonia edulis Seem.

BORAGINACEAE

Cordia subcordata Lam.

Heliotropium foertherianum Diane \& Hilger

CAPPARIDACEAE

Capparis cordifolia Lam.

CASUARINACEAE

Casuarina equisetifolia J. R. \& G. Forst.

CELASTRACEAE

e Cassine vitiensis (A.C. Sm.) A.C. Sm.

e Celastrus richii A. Gray

CLUSIACEAE

Calophyllum inophyllum $\mathrm{L}$.

e Calophyllum vitiense Turrill

Garcinia pseudoguttifera Seem.

COMBRETACEAE
Terminalia catappa $\mathrm{L}$.

Terminalia litoralis Seem.

e Terminalia vitiensis A.C. Sm.

CONNARACEAE

e Connarus pickeringii A. Gray

CONVOLVULACEAE

Evolvulus alsinoides (L.) L.

Ipomoea littoralis $\mathrm{B} 1$.

Ipomoea pes-caprae (L.) R. Br.

Merremia peltata (L.) Merr.

Operculina turpethum (L.) A. Silva Manso

CUNONIACEAE

e Geissois ternata A. Gray

e Weinmannia vitiensis Seem.

DICHAPETALACEAE

Dichapetalum vitiense (Seem.) Engl.

DILLENIACEAE

Dillenia biflora (A. Gray) Martelli

EBENACEAE

e Diospyros gillespiei (Fosb.) Kostermans

Diospyros major (Forst. f.) Bakh.

e Diospyros phlebodes (A.C. Sm.) A.C. Sm.

e Diospyros vitiensis Gillespie

EUPHORBIACEAE

Acalypha lanceolata Willd.

Acalypha repanda Muell. Arg.

e Claoxylon echinospermum Muell. Arg.

* Codiaeum variegatum (L.) A.H.L. Juss.

e Croton metallicus Seem.

Croton microtiglium Burkill

Euphorbia plumerioides Teijsm. ex Hassk.

EUPHORBIACEAE ctd

Excoecaria agallocha L.

Glochidion concolor Muell. Arg.

e Glochidion seemannii Muell. Arg.

e Glochidion vitiense (Muell. Arg.) Gillespie

Homalanthus nutans (Forst. f.) Guill.

Macaranga seemannii (Muell. Arg.) Muell. Arg.

Mallotus tiliifolius (B1.) Muell. Arg.

* Phyllanthus virgatus G. Forst.

Stillingia pacifica Muell. Arg.

FLACOURTIACEAE

e Casearia longifolia A.C. Sm.

Erythrospermum acuminatissimum (A. Gray) A.C. Sm.

e Flacourtia subintegra A.C. Sm.

e Homalium vitiense Benth.

Xylosma simulans A.C. Sm.

GESNERIACEAE

e Cyrtandra anthropophagorum Seem.

GOODENIACEAE

Scaevola sericea Vahl

GYROCARPACEAE

Gyrocarpus americanus Jacq.

HERNANDIACEAE

Hernandia nymphaeifolia (Presl) Kubitzi

HIPPOCRATEACEAE

e Salacia vitiensis A.C. Sm.

ICACINACEAE

e Citronella vitiensis R. Howard

LAMIACEAE

Leucas decemdentata (Willd.) Sm.

Plectranthus forsteri Benth.

LAURACEAE

Cassytha filiformis L.

e Litsea vitiana (Meissn.) Benth. \& Hook. f.

LEEACEAE

Leea indica (Burm. f.) Merr.

LEGUMINOSAE

Abrus precatorius L. 
Acacia simplex (Sparrman) Pedley

Caesalpinia bonduc (L.) Roxb.

Caesalpinia major (Medik.) Dandy \& Exell

Canavalia cathartica Thou.

Canavalia rosea (Sw.) DC.

Canavalia sericea A. Gray

e Cynometra insularis A.C. Sm.

Dendrolobium umbellatum (L.) Benth.

Derris trifoliata Lour.

Entada phaseoloides (L.) Merr.

Erythrina variegata $\mathrm{L}$.

* Inocarpus fagifer (Parkinson) Fosberg

Intsia bijuga (Colebr.) Kuntze

e Kingiodendron platycarpum B.L. Burtt Maniltoa grandiflora (A. Gray) Scheffer Milletia pinnata (L.) Panigrahi

Mucuna gigantea (Willd.) DC.

Ormocarpum orientale (Spreng.) Merr.

* Pueraria lobata (Willd.) Ohwi

Schleinitzia insularum (Guillemin) Burkart

e Serianthes vitiensis A. Gray

Tephrosia purpurea (L.) Pers.

Vigna marina (Burm.) Merr.

LOGANIACEAE

Geniostoma vitiense Gilg \& Benedict

LYTHRACEAE

Pemphis acidula J.R. \& G. Forst.

MALPIGIACEAE

e Hiptage myrtifolia A. Gray

MALVACEAE

Hibiscus tiliaceus L.

* Sida rhombifolia L.

Thespesia populnea (L.) Solander

Urena lobata $\mathrm{L}$.

MELASTOMATACEAE

e Medinilla ovalifolia (A. Gray) A.C. Sm.

Memecyclon vitiense A. Gray

MELIACEAE

e Aglaia vitiensis A.C. Sm.

Dysoxylum mollissimum Miq.

e Dysoxylum seemannii Gillespie

Vavaea amicorum Benth.

Xylocarpus granatum Koenig

MOLLUGINACEAE

Mollugo pentaphylla $\mathrm{L}$.

MORACEAE

e Ficus barclayana (Miq.) Summerhayes

e Ficus masonii Horne ex Baker

Ficus obliqua Forst. f.

e Ficus pritchardii Seem.

Ficus tinctoria Forst. f.

e Ficus vitiensis Seem.

Trophis scandens (Lour.) Hook. \& Arn.

MYRISTICACEAE

e Myristica chartacea Gillespie MYRSINACEAE

e Embelia deivanuae R.O. Gardner

e Maesa persicifolia A. Gray

Myrsine myricifolia A. Gray

MYRTACEAE

Decaspermum vitiense (A. Gray) Niedenzu

Eugenia reinwardtiana (B1.) DC.

Metrosideros collina (J.R. \& G. Forst.) A. Gray

Syzygium corynocarpum (A. Gray) C. Muell.

e Syzygium gillespiei Merr. \& Perry

e Syzygium gracilipes (A. Gray) Merr. \& Perry

* Syzygium malaccense (L.) Merr. \& Perry

Syzygium neurocalyx (A. Gray) Christophersen

Syzygium richii (A. Gray) Merrill \& Perry e Syzygium rubescens (A. Gray) C. Muell.

e Syzygium seemannianum Merr. \& Perry

NYCTAGINACEAE

Boerhavia glabrata B1.

NYCTAGINACEAE ctd

Pisonia grandis $\mathrm{R}$. Br.

OLACACEAE

Ximenia americana $\mathrm{L}$.

OLEACEAE

Chionanthus vitiensis (Seem.) A.C. Sm.

Jasminum didymum $\mathrm{G}$. Forst.

PEPEROMIACEAE

Peperomia blanda Kunth

e $P \quad$ eperomia lasiostigma C. DC.

PIPERACEAE

Piper puberulum Benth

PITTOSPORACEAE

Pittosporum brackenridgei A. Gray

Pittosporum rhytidocarpum A. Gray

PORTULACACEAE

Portulaca samoensis Poelln.

RHAMNACEAE

Alphitonia franguloides A. Gray

Alphitonia zizyphoides (Spreng.) A. Gray

Colubrina asiatica (L.) Brongn.

Rhamnella vitiensis (Benth.) A.C. Sm.

Smythea lanceata (Tul.) Summerhayes

Ventilago vitiensis A. Gray

RHIZOPHORACEAE

Bruguiera gymnorrhiza (L.) Lam.

Rhizophora stylosa Griffith

RUBIACEAE

Antirhea inconspicua (Seem.) Christophersen

Badusa corymbifera (Forst. f.) A. Gray

e Dolicholobium oblongifolium A. Gray

e Gardenia grievei Horne ex Baker

Guettarda speciosa L.

e Guettarda wayaensis R.O. Gardner

Hedyotis lapeyrousii DC.

e Ixora vitiensis A. Gray

e Mastixiodendron flavidum (Seem.) A.C. Sm.

Morinda citrifolia L.

Morinda myrtifolia A. Gray

Mussaenda raiateensis J.W. Moore

e Ophiorrhiza laxa A. Gray

e Ophiorrhiza peploides A. Gray

e Psychotria amoena A.C. Sm.

e Psychotria tephrosantha A. Gray

e Psychotria volii R.O. Gardner

Psydrax odorata (G. Forst.) A.C. Sm. \& S.P.

Darwin

Tarenna sambucina (G. Forst.) Durand ex Drake RUTACEAE

Euodia hortensis J.R. \& G. Forst.

Melicope cucullata (Gillespie) A.C. Sm.

Micromelum minutum (Forst. f.) Seem.

SANTALACEAE

Santalum yasi Seem.

SAPINDACEAE

Arytera brackenridgei (A. Gray) Radlk.

e Cupaniopsis leptobotrys (A. Gr.) Radlk.

Dodonaea viscosa (L.) Jacq.

Elattostachys apetala Radlk.

Guioa rhoifolia (A. Gray) Radlk.

* Pometia pinnata J.R. \& G. Forst.

Sapindus vitiensis A. Gray

SAPOTACEAE

Burckella richii (A. Gray) Lam

e Manilkara vitiensis (H.J. Lam \& B. Meeuse 
e Palaquium fidjiense Pierre ex Dubard Planchonella garberi Christopherson

e Planchonella smithii (van Royen) A.C. Sm. Planchonella tahitensis (Nadeaud) Pierre ex Dubard SOLANACEAE

Solanum americanum Mill.

Solanum vitiense Seem.

STERCULIACEAE

Heritiera littoralis Ait.

Kleinhovia hospita L.

e Melochia degeneriana A.C. Sm.

THYMELAEACEAE

Phaleria disperma (Forst. f.) Baill.

e Phaleria ixoroides Fosb.

e Phaleria lanceolata (A. Gray) Gilg

Wikstroemia coriacea Seem.

TILIACEAE

Grewia crenata (J. R. \& G. Forst.) Schinz \& Guillaumin

Trichospermum richii (A. Gray) Seem.

* Triumfetta rhomboidea Jacq.
ULMACEAE

Parasponia andersonii (Planch.) Planch. Trema cannabina Lour.

URTICACEAE

Boehmeria virgata (Forst. f.) Guillemin

Cypholophus heterophyllus (Wedd.) Wedd.

Dendrocnide harveyi (Seem.) Chew

Leucosyke corymbulosa (Wedd.) Wedd.

Pipturus argenteus (Forst. f.) Wedd.

Procris pedunculata (J.R. \& G. Forst.) Wedd.

VERBENACEAE

Clerodendrum inerme (L.) Gaertn.

e Premna protrusa A.C. Sm. \& S. Darwin

Premna serratifolia $\mathrm{L}$.

Vitex trifolia $\mathrm{L}$.

VIOLACEAE

Agatea violaris A. Gray

Rinorea benghalensis (Wall.) Kuntze

VITACEAE

e Tetrastigma vitiense (A. Gray) A.C. Sm. 